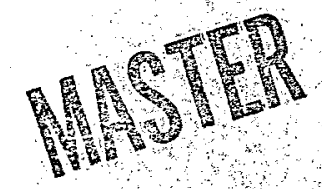

\title{
DETERMINATION OF MOISTURE IN LOW-RANK COALS
}

BY JOHN B. GOODMAN, MANUEL GOMEZ, AND V F, PARRY
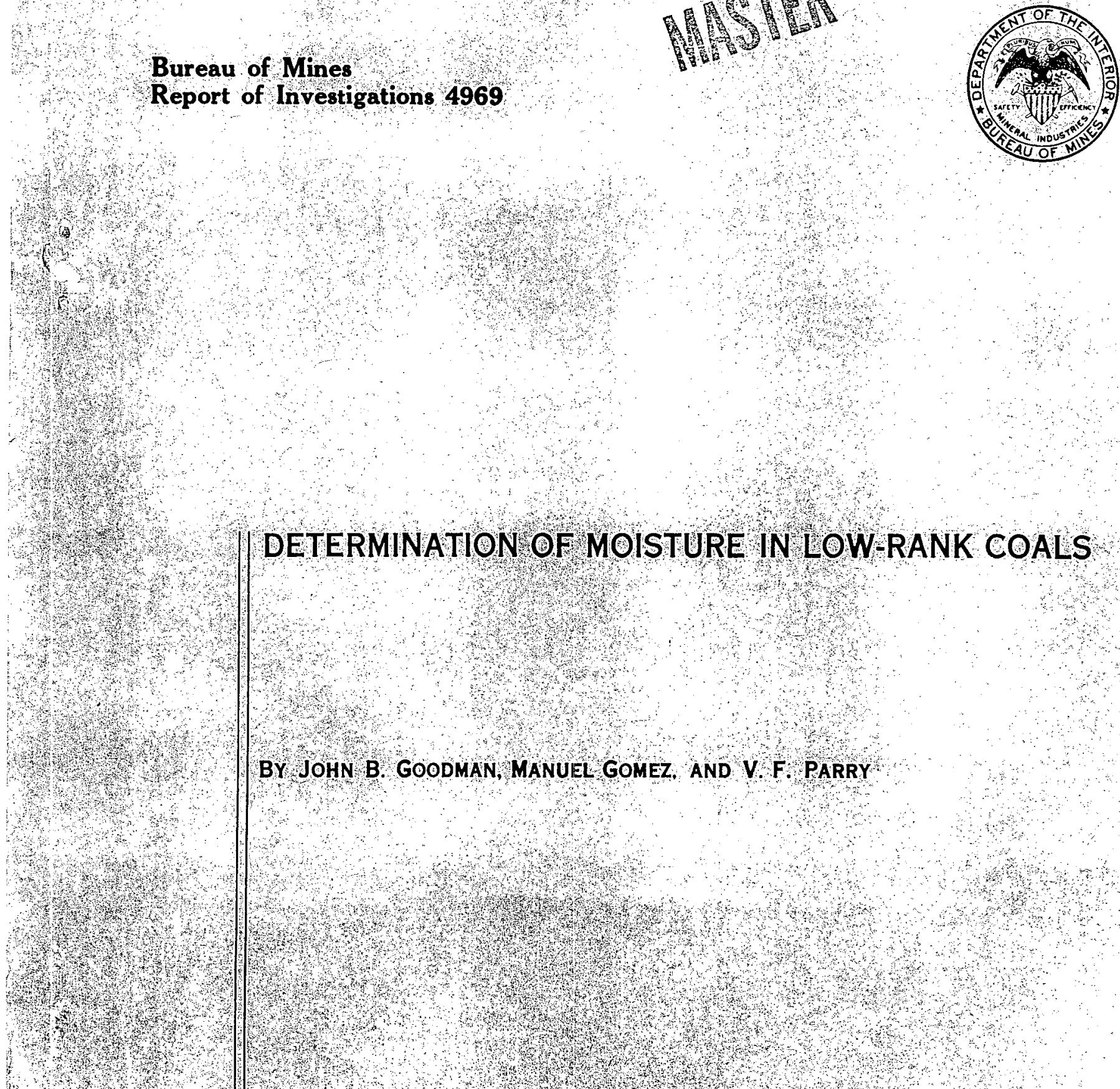

United States Department of the Interior__ May 1953 


\section{DETERMINATION OF MOISTURE IN LOW-RANK COALS}

By John B. Goodman, Manuel Gomez, and V. F. Parry

$* * * * * *$ * * Report of Investigations 4969

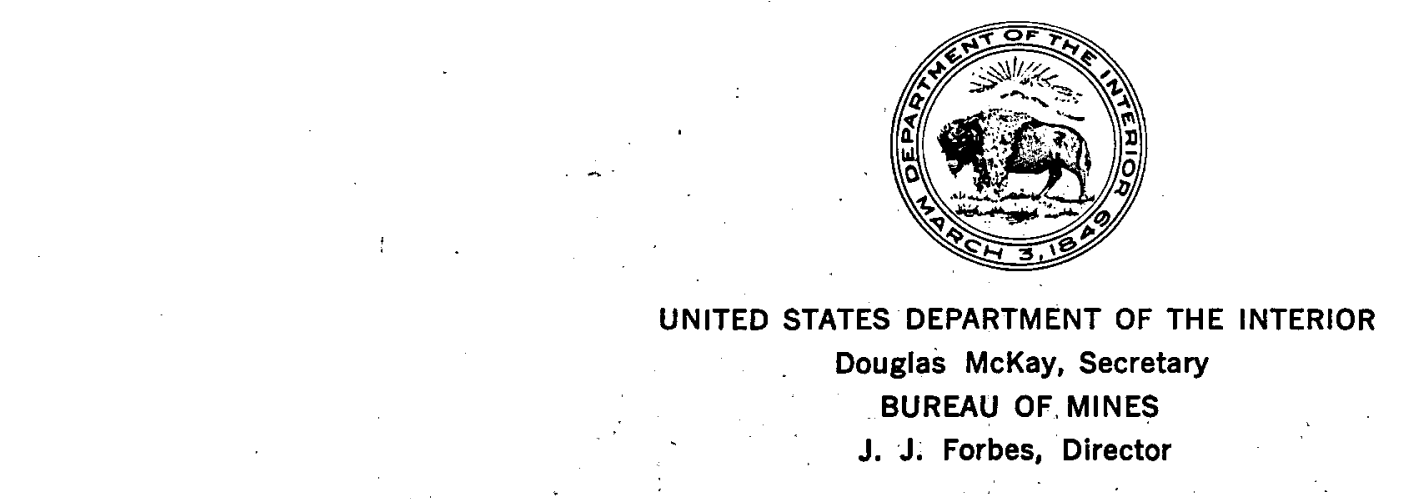

Work on manuscript completed September 1952. The Bureau of Mines will welcome reprinting of this paper, provided the following footnote- acknowledgment is made: "Reprinted from Bureau of Mines Report of Investigations 4969."

May 1953 


\section{DISCLAIMER}

This report was prepared as an account of work sponsored by an agency of the United States Government. Neither the United States Government nor any agency Thereof, nor any of their employees, makes any warranty, express or implied, or assumes any legal liability or responsibility for the accuracy, completeness, or usefulness of any information, apparatus, product, or process disclosed, or represents that its use would not infringe privately owned rights. Reference herein to any specific commercial product, process, or service by trade name, trademark, manufacturer, or otherwise does not necessarily constitute or imply its endorsement, recommendation, or favoring by the United States Government or any agency thereof. The views and opinions of authors expressed herein do not necessarily state or reflect those of the United States Government or any agency thereof. 


\section{DISCLAIMER}

Portions of this document may be illegible in electronic image products. Images are produced from the best available original document. 


\section{DETERMINATION OF MOISTURE IN LOW-RANK COALS}

by

John B. Goodman, $\mathrm{V}$ Manuel Gomez, 2 / and V. F. Parry 3 /

CONIENTS

Page

Introduction................................... I

Summary and conclusions.......................... 5

Acknowledgments............................... 5

Procedure for comparing methods...................... 5

Description of methods.$\ldots \ldots \ldots \ldots \ldots \ldots \ldots \ldots \ldots \ldots \ldots \ldots \ldots \ldots$

Schoch oil dehydration........................ 7

Xylol distillation........................... 8

A.S.T.M. and Bureau of Mines method for moisture determinations ........................... 8

Vacuum-oven method.......................... 8

Analytical results $\ldots \ldots \ldots \ldots \ldots \ldots \ldots \ldots \ldots \ldots \ldots \ldots \ldots \ldots \ldots \ldots$

Drying at $110^{\circ} \mathrm{C}$. with natural circulation of air from the room. I5 Efficacy of distiliation methods for moisture evaluation....... 16

I/ Chemical engineer, Coal Branch, Region IV, Fuels and Explosives Division, Denver, Colo.

2/ Chemist, Coal Branch, Region IV, Fuels and Explosives Division, Denver, Colo.:

3/ Chief, Coal Branch, Region IV; Fuels and Explosives Division, Denver, Colo." 
1. Comparison of air-drying methods................ 7

2. Analyses of coals studied in comparing methods for deter-

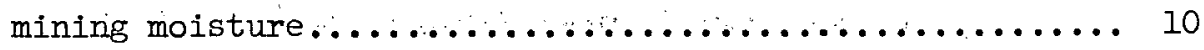

3. Comparison of methods for determining moisture in coal.... 11

4. Comparison of oven-drying methods for determining moisture

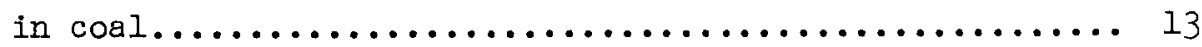

5. Deviation between various methods.................. 14

6. Effect of air-drying time and coal size using dried air.... 15

7. Effect of air-drying time using normal laboratory air..... 16

8. Xylol distillation on $1 / 2-$ by $1 / 4-$ inch coal ............ 16

9. Effect of temperature on percentage of water measured as determined by xylol distillation method............ I7

10. Effect of temperature on percentage of water measured as determined by Schoch oil-distillation method......... 17

11. Results of determination of moisture at different

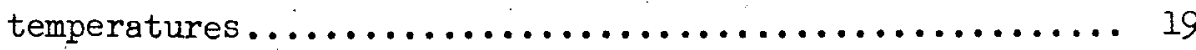

\section{ILLUSTRATIONS}

Follows

Fig.

page

I. Sampling procedure for comparing methods for determining moisture in coal......................

2. Air-drying characteristics for raw and treated coal and lignites shown by A.S.T.M. standard method D-271-48.. 2

3. Comparison of oven-drying methods.............. 12

4. Influence of temperature on extent of moisture removed by Schoch oil-dehydration method.............. 12 


\section{INTRODUCTION}

The need for an accurate and precise analytical method for determining molsture in coals of high water content has been recognized by the coal industry as well as the fuel technologist. Interest in this particular phase of coal technology extends back to the early work of German investigators on the brown coals of Central Europe. Studies by these workers led to the establishment of a direct immiscible liquid-distillation method 4 as the accepted moisture-determining technique in European laboratories. Direct moisture-determining methods, those methods that utilize various techniques to drive of $f$ the water from a given sample of coal and either collect the water in a calibrated receiver or selectively trap the water driven of in a suitable absorber, have found little favor in the United States. They have been treated merely as research tools. 5 /.

4 Marcusson, J., (Determination of Water and Acid Content of Grease): Mitt. konigl. Materialprufungsamt zu Gross-Lichterfelde West, vol. 22, 1904, p. 48.

: Schlapfer, P., (The Water Determination in Solid and Liquid Fuels by Distillation with Xylol): Ztscher. angew. Chem., vol. 27, 1914, pp. 53-56.

Hinrichsen, F. W., and Taczak, S., (Testing Fuels): Mitt. k"nigl. Materialprufungsamt zu Gross-Lichterfelde West, vol. 32, 1914, pp. 273-336. (Testing of Fuels): Stahl u. Eisen, vol. 35, 1915, pp. 2l-22.

Mertens, E., (On the Oxidation of Coal and the Determination of Water): Bull. federation ind. chim. Belg., vol. 1, 1922, pp: 361-364.

Erdmann, E., (The Water Content of Brown Coal, Its Influence on the Calorific Value, and Its Analytical Determination): Braunkohle, vol. 23, 1924, pp. 49-56.

Schaefer, Kurt, (An Automatic Apparatus for the' Determination of Water in Coals, Tars, and Oils): Chem,-2tg., vol. 43, 1924, p. 761 .

Broche, H., (Determination of Moisture Content of Coal and Coal Dust): Braunkohle, vol. 26, 1927, pp. 5-9.

Bunte, K., New Methods for Fuel Analys is: Trans. World Power Conf., Fuel Conf., London, 1928; vol. 2, pp. 467-481; in German, pp. 481"-493.

Faber, Alfred, (Rapld. Water Determination of Dry Lignite for Briquet Manufacture): Angew. Chem., vol. 42, 1929, pp. 406, 407.

5/ Myhill, A. R., Determination of Moisture in Coals:' Gás Jour.; vol. 150, 1920, p. 21.

Davidson, W. B., Coal Sampling and Analysis:. Fuel Econ. Rev., vol. 9; 1930, pp. 5-14.

Partington, N., Some Coal-Testing Problems: Gas Eng., vol. 47,; 1930, pp. 27-38.

Staemmler, C., (The Determination of Water in Brown Coal From New Points of View With Particular Refereñce to Volatile Coal Constituents): Chem.-2tg., vol. 54, 1930, p. 928.

Wood, W. H., Convenient Method of Deteimining Moisture in Coal... Combustion, vol. 7 , No. 2, 1935, p. 16.

Alexander, H. B., A New Moisture Tube: Ind. Eng. Chem., anal. ed., vol. 8, 1936, p. 314 .

Guy, T. W., Need for a Standard Method for Determining Surface Moisture in Coal: Am. Inst. Min. and Met. Eng., Tech. Pub. 935, 1938, 20 pp. 
The problem of moisture determination in low-rank coals of the United States has not been given much consideration because such coals contribute only about 2 percent $6 /$ of the total United States production. With renewed activity in low-temperature carbonization and with the growth of interest in coal and coal-tar hydrogenation, the American coals of lower rank containing 20 to 40 percent bed moisture will be subjected to extensive investigation. If the low-rank coals of the United States are to be accurately appraised, the need for qualitative and quantitative analytical procedures becomes more pronounced. These coals, especially the lignites of Texas and North Dakota, are highly susceptible to oxidation, a process that proceeds to a greater or less extent when low-rank, high-moisture coals are treated by oven-drying methods. The extent of this atmospheric oxidation has been described and evaluated by numerous, workers.I/

In many respects, the problem of moisture determination in low-rank coals, those found in the United States and the high-moisture coals of Central Europe, is similar. Conversely," the problem of moisture determination assumes a different aspect when the coals of the eastern and the middle-west sections of the United States are considered. Present methods, the loss in weight gravimetric-type procedures, serve adequately to test these low-moisture coals. The determination of moisture in coals containing 20 to 40. percent water should be approached from a direct method rather than from an indirect gravimetric-type procedure because of the oxidative tendencies of these coals and the demonstrated inability of a loss-in-weight technique to remove all the water in a given sample of coal.

The method employed by the Bureau of Mines $8 /$ for moisture determination, and its counterpart, the A.S.T.M.2\% standard procedure, were evolved after a consideration of the best and most convenient methods for eastern United States coals, but it is. now indicated that these techniques are not suitable for the lower rank coals. It should be recognized that a loss in weight of sample does not necessarily mean an equivalent loss of water. Moreover, the loss in weight can not be taken to mean that all the water in the coal has been driven off. Consideration should be given to better methods for moisture determination applicable to the lower rank, coals of the western United States.

6/ Bureau of Mines, Minerals Yearbook, 1948, pp. 271 and 342 .

I) Archibald, E. H., and Lawrence, J. N., Determination of Moisture in Coal: Jour. Ind. Eng. Chem., vol. 4, 1912, pp. 258-262.

Winmill, T. F., The Estimation of Moisture in Coal:' Colliery Guard., vol. 3, 1916, pp. 1135-1138.

Mertens, E., (On the Oxidation of Coal and the Determination of Water): Bull. federation ind. chim. Belg., vol. 1, 1922, pp. 301-304.

Kreulen, D. J. W., The Change in Weight of Coal During the Prolonged Oxidation at Low-Temperature: Fuel, vol. 5, 1926; pp. 345-346.

Gauger, A. W.; Condition of Water in Coals of Various Ranks: Trans. Am. Inst. Min. and Met. Fng., vol. 101, 1932, pp. 148-164.

Stansfield, E., and Gilbert, K. C., Moisture Determination for Coal Classification: Trans: Am. Inst. Min. and Met. Eng., vol. 101, 1932, pp. 125-147.

Francis, Wilfred, and Morris, H. M., Relationship Between Oxidizability and Composition of Coal: Bureau of Mines Bull."340, 1931, 44 pp.

8/ Fieldner, A. C., and Selvig, W. A., The Determination of Moisture in Coke: Bureau of Mines Tech. Paper 148, 19.17, 14 pp.

Stanton, F. M., Fieldner, A. C., and Selvig, W. A., Methods of Analyzing Coal and Coke: Bureau of Mines Tech. Paper 8, 1939, 59. pp. Revised:

Fieldner, A.C., and Selvig; W. A., Methods of Analyzing Coal and Coke: Bureau of Mines Bull. 492, 1951, 51 pp.

9/ American Society for Testing Materials, 1949 Book of A.S.T.M. Standards: Part 5, 'Philadelphia, 1949, pp. 583-609. 


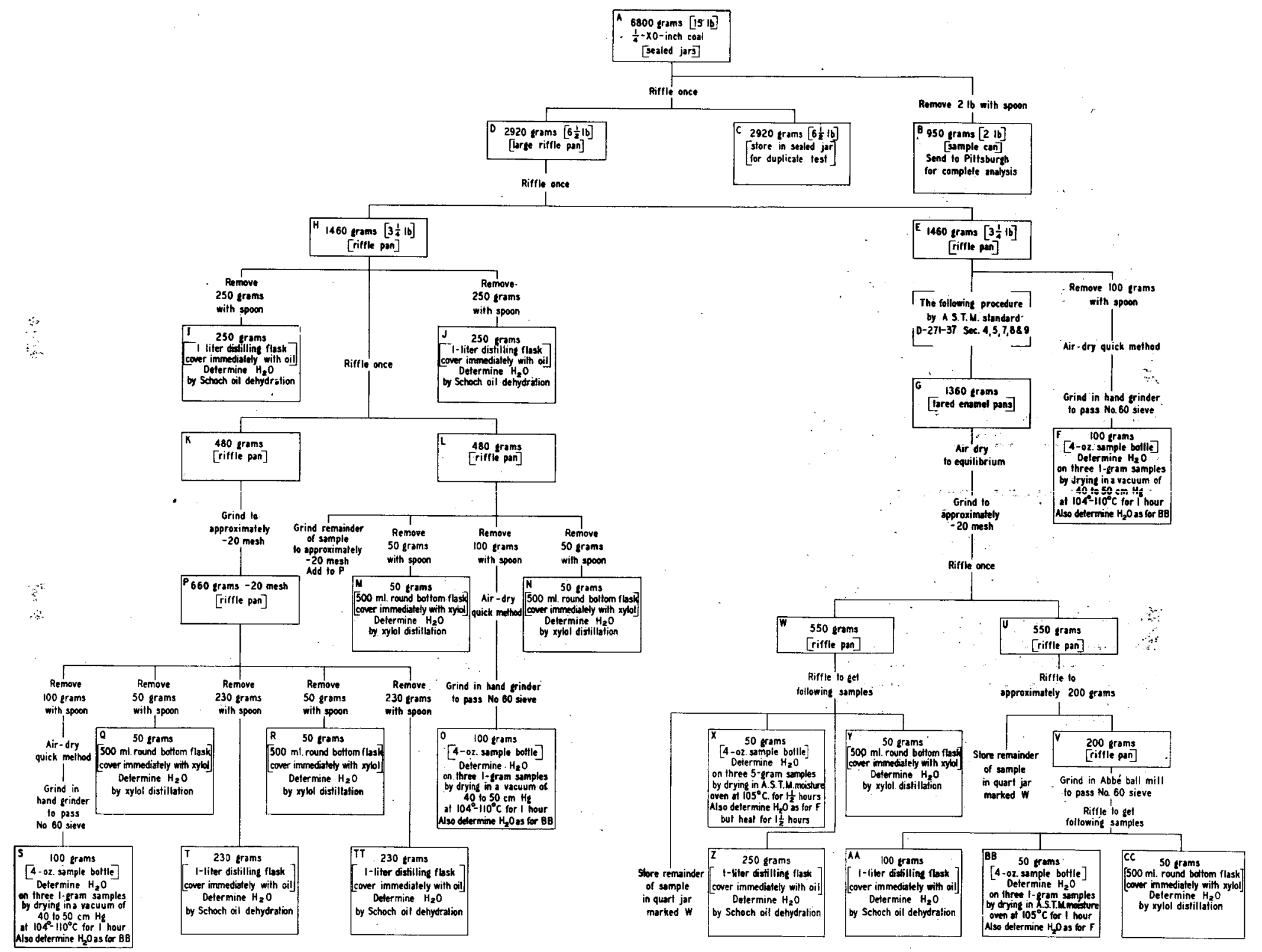

Figure 1. - Sampling procedure for comparison of methods for determining moisture in coal. 


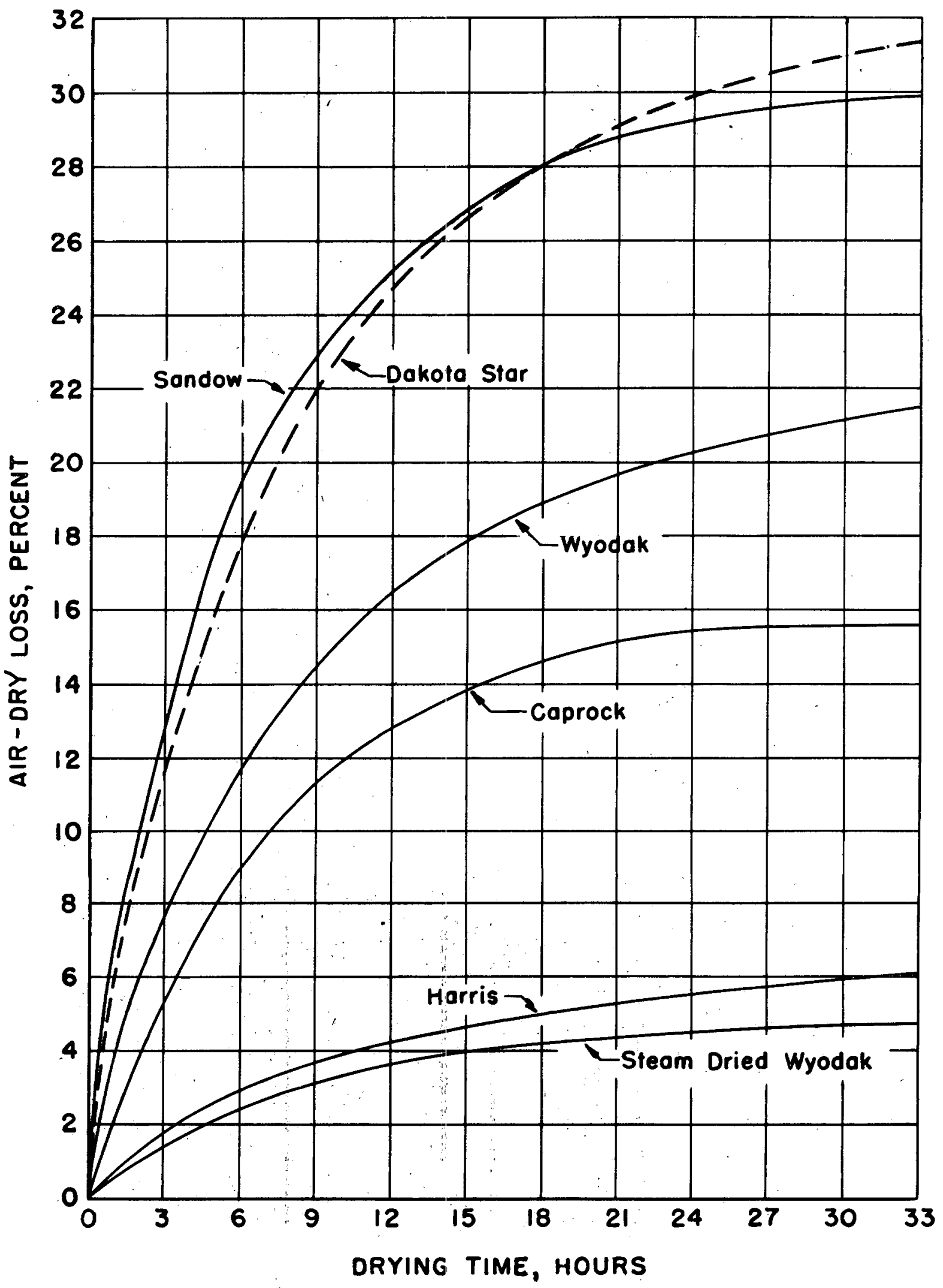

Figure 2 - Air-drying characteristics for raw and treated coal and lignites shiown by A.S.T.M. standard method D-271-48. 
Several factors have retarded the introduction of an effective analytical procedure applicable to all coals whatever their moisture content. The first has been the failure to adopt a direct-type moisture-determining procedure. Several techniques have been reported in the literature, 10/ but none have been given serious consideration in the United States. Secondly, water in coalll has not been clearly defined. Conflicting terms, such as "inherent molsture," "vein moisture," "intrinsic moisture," "bed moisture," and "surface moisture" need revaluation. In actual practice they may be considered synonomous, with the exception of surface molsture, and may be taken to mean that water contained in the coal exclusive of water introduced through mining procedure or coal-preparation techniques. Surface molsture takes into account this latter extraneous water. Further confusion arises with the use of the terms "free water," "inherent water," "hygroscopic water," "bound water," and "combined water:" Again, with the exception of the term "free water," all these terms have been used loosely and interchangeably by various people. An attempt to clarify and simplify these definitions has been made by Gauger, 12/. who stated that the "water recoverable from coal is obtained from the following sources: (1) Decomposition of organic molecules (sometimes called 'combined water!), (2) surface adsorbed water, (3) capillary condensed water, (4) dissolved water, (5) water of hydration of inorganic constituents of the coal." In view of the conflicting opinions, an attempt has been made to arrive at a term equivalent to water recoverable from coal up to $130^{\circ}-140^{\circ} \mathrm{C}$., the boiling temperature of isomeric xylene mixtures, irrespective of its source. The term "total-determined moisture" will be useful to designate the quantitatively measured water in a given sample of coal.

Whatever the method employed, it must be able to ascertain the total water content of the high-moisture lignite and subbituminous coals and depress the oxidative tendencies of these coals: A suitable method for moisture determination must be both practical and accurate, and it is indicated that present gravimetric-type procedures, which employ 1- or 5-gram.samples, are nelther practical nor accurate, with respect to low-rank coal testing, for the following reasons:

10/ See footnotes 4 and 6; also Lunn, C. A., and Knoblock, G. H., Moisture Oven Used in the Analysis of Coal: Am. Gas. Assoc. Monthly, vol. 4, No. 9, 1922, pp. 571576.

Simek, B. G., Ludmila, J., and Stanclova, B., (The Determination of Moisture in Coal): Mitt. Kohlenforsch.-Inst. Prag., vol.. 1, No. 4, 1932, pp. 242-253.

Kaiser, M., and Spallek, F', (The Determination of Moisture in Briquetting Coal With Particular Regard to the Brabender Rapid Moisture Tester): Braunkohle, vol. 38, 1939, pp.65-70, 84-91.

11/ Somermeier, E. E., Moisture in Coal: Jour. Am. Chem. Soc.; vol. 28, 1906, pp. $1630-1638$.

Porter, H. C., and Ralston, O. C., Scme Properties of the Water in Coal: Bureau of Mines, Tech. Paper 113, 1916, 30 pp.

Coles, G., The Specific Heat of Coal and its Relation to Composition: Colliery Guard., vol. 126, No. 3277, oct.19, 1923, pp. 973-974. Jour. Soc. Chem. Ind.,

vol. 42, 1923, pp. 435-439.
Mott, R. A., The Dewatering and Drying of Coal: Trans: World Power Conference, Fuel Conf., London, 1929, vol. 1, fp. 241-258.

Vondracek, $R_{.}$, and Mosendz, L., Molsture Determination in Coals by Drying in Vacuo: Trans. World Power Conference, Fuel Conf., London, 1929, vol. 1, pp. $281-284$.

Koda, R., Nature of Japanese Lignite and Its Hygroscopic Constituent: Proc. World Eng. Cong., Tokyo, 1931, vol. 32, pp. 269-270.

12/ Work cited in footnote 7 . 
(1) The physical limitations encountered in preparing and obtaining a representative sample preclude using a l-gram or 5-gram sample for testing.

(2) Excessive handling of samples, the result of crushing and fine grinding demanded by specifications of gravimetric-type testing procedures, limit the accuracy in high-moisture coals through rapid loss of water.

(3) Loss in weight of sample through heating cannot be construed to mean a loss of an equivalent weight of water. When high-moisture coals are subjected to heat, several processes are in evidence, two of which are important:

(a) Loss in weight of sample due to water loss.

(b) Gain in weight of sample due to the oxidative tendencies of these high-moisture low-rank coals.

Moisture testing under these conditions is usually a compromise between these two phenomena. Gravimetric procedures, devised primarily for coals of low moisture content and limited by the conditions of the test, do not take into account the phenomenon of oxidation; therefore, they cannot be expected to yield quantitative results for high-moisture coals.

The method of water extraction through xylene distillation offers good possibilities of satisfying the limitations set by the low-rank, high-moisture coals. Schlapfer,13/ Hinrichsen and Taczak, 14/ and Broche15/ concluded after extensive experimentation that the yxlene distillation method was the most exact method. Their findings indicated that the total amount of water in a given sample of coal, excluding that water held in a strong chemical combination within the coal substance, was recoverable through xylene distillation. It is to be noted that incipient coal decomposition16/ begins above 1300-1400.C., the boiling point of isomeric xylene mixtures. In the xylene-distillation test, coal decomposition is confined to loose, inorganic chemical combinations, such as hydrates (sols and gels), present in the coal. The oxidation of the coal is prevented, since the xylene liquid and vapor phases serve to insulate and cover the coal particle at all times during the test.

The method accepted by the A.S.T.M. is the oven-drying procedure, which employs heat in a current of air dried over sulfuric acid. That method is satisfactory for high-rank coals simply because of its applicability to low-moisture coals. It fails as a method when it is applied to test lignites and subbituminous coals. These coals contain 20 to 40 percent water and are easily oxidized when subjected to indirect gravimetric procedures. The moisture value, obtained by indirect heat treatment, for a sample of low-rank coal is influenced in part by the amount of water driven off during the period of the test and in part by the oxidation of the coal that occurred during the test. One cannot state with accuracy that the loss in weight of the sample is due to the loss of all the measurable water in that sample.

See footnote 4.

See footnote 4.

See footnote 4 .

Mack, E., and Hulett, G. A., The Water Content of Coal With Some Ideas on the Genesis and Nature of Coal: Am. Jour. Sci., vol. 43, 1917, pp. 89-110.

Mack, E., Hulett, G. A., and Smythe, C. P., Moisture Content of Some Typical Coals: Am. Jour. Sci., vol. 45, 1918, pp. 174-184. 
of particular interest: is the method introduced by Schoch, 17/ which is applicable to high moisture coals : In essence, it is a distillation carried to a temperature of $225^{\circ} \mathrm{C}$., at which point it is stopped. The method is open to the same limitations as any distillation procedure: Solublilty of water in the distilling liquid, temperature of the water distilled over, and meniscus corrections. Higher temperature of distillation may cause some breakdown of coal substance; however, the results obtained by this method are no higher than those obtained by the xylol procedure: This method is cumbersome and does not lend itself readily as a method for routine practice or laboratory control.

\section{SUMMARY AND CONCLUSIONS.}

A serles of comparative tests has been made testing the validity of moisturedetermination methods. Results obtained from this study indicate that oven-drying methods are inadequate to determine the moisture content of low-rank, high-moisture cools. Since more water is actually recovered and measured by any of the distillation methods than can be determined under comparable conditions by oven-drying methods, it is concluded that these volumetric methods, which give the most if not all the recoverable water short of that derived from coal decomposition, are the most accurate.. The problem of air oxidation in the low-rank, high-moisture coals is eliminated almost entirely by distillation methods; the coal particle is insulated and protected at all times by the liquid or vapor phases of the oil or xylol.

Among distillation methods, the Schoch oil-dehydration and the xylol distillation methods closely parallez. In many instances, the moisture values obtained by the xylol methodare higher than those obtained by the Schoch method, despite its lower operating temperature... It can be concluded that whatever moisture, short of chemical decomposition, is contained in the coal sample may be determined by either the xylol or Schoch methods with equal precision. Considering the simplicity of the method, the size of the sample taken, and the time.required for one determination, the xylol procedure is the better of the two methods. The technique has been standardized to the point where the average technician with a minimum of instruction soon attains acceptable proficiency.

The Schoch method, in spite of its apparent accuracy; is cumbersome and sub ject to certain limitations:- The test must be watched over all its temperature range; and the method is best performed when only one determination is attempted. The azeotropic distillation method using xylol, on the other hand, involves smaller amounts of sample and reagent. . Only the minimum amount of observation is required. Its accuracy and simplicity lend it as an. excelient method for either routine or control work, and it is particularly amenable to the lower-rank, high-moisture coals and lignites.

\section{$\because \quad \cdots \quad$ ACKNOWLEDGMENTS}

The assistance and cooperation of $H$. M. Cooper, formerly chief, Coal Analys is Section, and R.F. Abernethy; chief, Coall Analysis: Section, Bureau of Mines, Pittsburgh, $\mathrm{Pa}$. , is gratefully acknowlediged. This report was prepared under the general direction of Dr. L. C. McCabe, chief, Fuels and Explosives Division, and J. H. East, Jr., Reglonal Director, Region IV, Bureau of Mines.

\section{PROCEDURE FOR COMPARING METHODS}

In an attempt to prove the need for a direct method of molsture determination, a. series of experiments was conducted. Six coals representative of low-rank coals of varying moisture content were chosen for testing. The source identification as

\footnotetext{
17) Schoch, E. P., Oil Dehydration of North American Lignites: Ind. Eng. Chem., vol. 31,1939, p. 1489.
} 
well as, the analysis of samples are given in table 2. These include 2 lignites (Sandow and Dakota Star) and 3 coals of subbituminous rank. (Wyodak, Harris, and Caprock).. In order to apply the methods to the testing of moisture content of dried coals, a sample of steam-dried Wyodak was included in the series.

At the outset, a survey of the literature showed that the xylol method as outlined by Schlapfer was the superior procedure. More concordant results were attained by this method with improvement in apparatus and manipulation technique. The method proposed by Schoch was also reviewed because of its probable accuracy and simplicity. It was decided to compare the two direct methods with the A.S.T.M. procedure and a vacuum-oven technique.18/ Comparative tests on the accuracy of the four methods were made on duplicate samples of subbituminous coal and lignite. In addition to the accuracy of results, the methods were treated from the standpoint of ease and convenience of handling.

The method employed in comparative testing involved collecting representative samples of the five coals in accordance with A.S.T.M. sampling procedure. Approximately 15 pounds or 6,800 grams of $1 / 4$-inch byi 0 coal was collected and stored in sealed jars. When ready for testing, the sample was thoroughly mixed. Two pounds were removed with a' spoon from various portions of the mixing plie; that sample was sent to' the Central Experiment Station at Pittsburgh for complete analysis. 'The remaining 13 pounds was riffled once; half of this sample constituted the test sample, and the other half was stored in a sealed jar for duplicate testing. It was realized that speed was essential in the sampling procedure if samples were to have identical moisture content.

The test sample was riffled once again into equal halves. Each half was then subjected to a distinct series of tests involving the four methods under study: Xylol distillation, Schoch oil dehydration, A.S.T.M. oven drying, and the vacuumoven method. The two series of tests were carried out as outlined in the chart shown as figure 1.

This procedure called for testing a coal sample on an as-received basis and again on the air-dried basis. On the as-received basis, 2 samples of $1 / 4$-inch by 0 and 2 samples of minus-20-mesh coal were determined by the Schoch method. $:$ Two samples of $1 / 4$-inch by 0 and two samples of minus-20-mesh coal were determined by the xylol distillation method. The sample sent to the Pittsburgh Station served as a comparison with.A.S.T.M. methods. T'wo samples of the fresh coal were air-dried and ground in a hand grinder to pass a No. 60 sieve. Moisture on this air-dried coal was determined by drying three l-gram samples in a vacuum oven at a reduced pressure of 40 to $50 \mathrm{~cm}$. Hg at $104^{\circ}$ to $110^{\circ} \mathrm{C}$. for 1 hour.

A second set of tests constituted the air-dried determinations. Strict adherence to the procedure set forth by A.S.T.M. Standards (D-271-48 Sec. 4, 5, 7, 8, and 9) 19/ was maintained. Coal that was air dried to equilibrium was tested by the 4 methods on minus-20-mesh and minus-60-mesh samples.

Air drying of the 6 coals under study according to A.S.T.M. (D-271-48) approached an equilibrium after 30 hours. The moisture loss became constant provided the humidity remained constant. In this study, with an average relative humidity of 5 percent throughout the period of testing, the air-drying equilibrium was reached when approximately 75 percent of the total moisture was removed. The air-drying loss as exhibited by these six coals is shown by figure 2 .

18/ British Standard Specifications for the Sampling and Analys is of Coal, 420, British Eng. Standards Assoc., 1931.

19/ See footnote 9 . 
The air-drying procedure was tested by comparing the A.S.T.M. (D-271-48) technique with the electric-drying-oven technique in which a sample of coal is heated in an oven at $104^{\circ}$ to $110^{\circ} \mathrm{C}$. for 1 to 3 hours. The results of this experiment are tabulated in table 1.. The electric-drying-oven technique is open to criticism because it will allow some oxidation of the sample. This air-drying step would be avoided altogether if a direct method for moisture evaluation were introduced.

TABLE 1. - Comparison of alr-drying methods

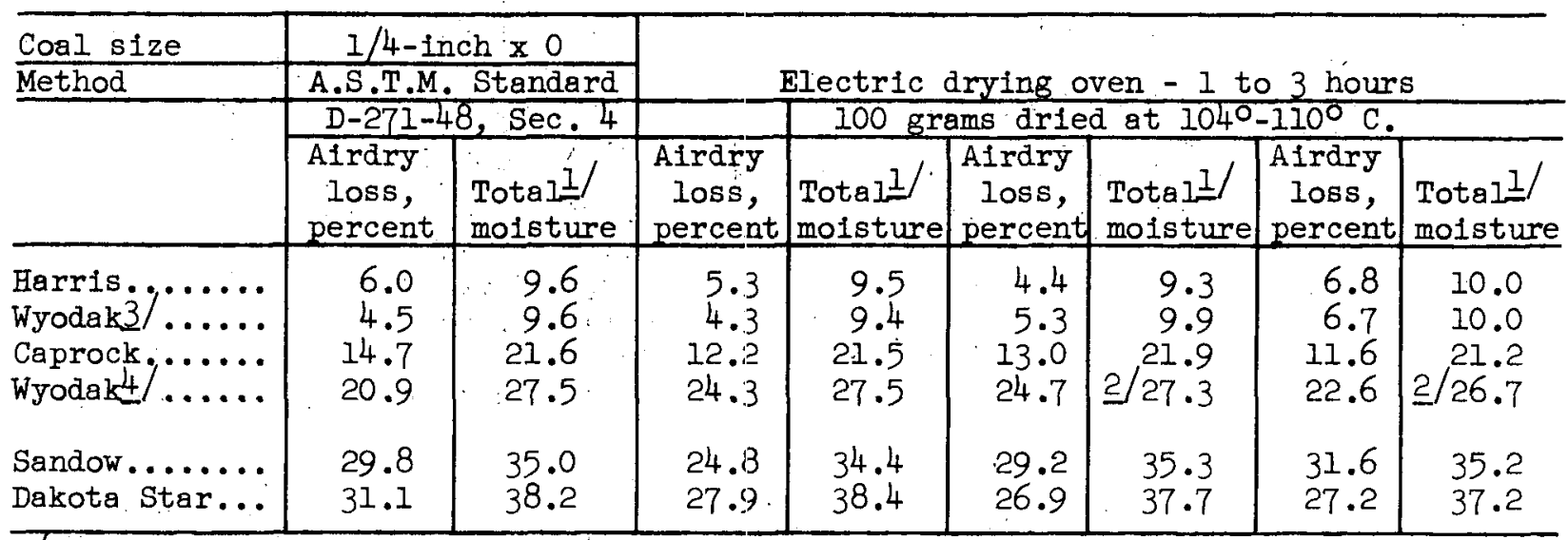

If Average molsture as determined in the A.S.T.M. moisture oven on 3 l-gram samples of the coal ground to minus-60-mesh.

2/ Same as footnote 1, except that moisture was determined in vacuum oven, which gave an average of 0.5 percent less total moisture on all coals tested than that determined by the A.S.T.M. molsture oven.

3/. Steam dried.

\section{DESCRIPTION OF METHODS}

\section{Schoch O.I Dehydration}

A sample of coat approxlmating 250 erams is welghed to \pm 0.1 gram. The coal is introduced into the distilling flask, and enough water-white kerosine is added to cover the sample; a volume of 400 to $500 \mathrm{ml}$. of kerosine is adequate. The flask is next placed in a hemispherical heating meintle connected to a variabile voltage autotransformer. The sidearm is connected to $a$ condenser, which delivers the condensate into a thistle tube extending into a $100-\mathrm{ml}$. volumetric flask; a thermometer is placed in the distilling flask so that the bulb is immersed in kerosine. The contents are heated gradually to avoid severe bumping until a temperature of $225^{\circ} \mathrm{C}$. is reached. The entire distillation time may require $1-i / 2$ to 2 hours. When a temperature of $225^{\circ} \mathrm{C}$. is reached the heating is discontinued and the flask withdrawn from the condenser.' Droplets of water adherirg to the condenser walls are washed down, first by rinsing with kerosine, and second, by mechanically swabbing or wiplng the inner condenser tube with an oil-resistant rubber-washer swab followed by a kerosine rinse.

From a burette, water is added to the volumetric flask containing the condensate to bring the water to the mark. The added water is subtracted from $100 \mathrm{ml}$. to obtain the weight of the water given off by the coal. The percentage of moisture in the sample of coal is calculated by dividing the weight of the water driven off by the weight of the coal sample taken for analysis, and that result is multiplied by 100 . 


\section{Xylol Distillation}

- A sample of coal 1/4-inch by 0 in size, riffled to approximately 100 grams (depending upon the moisture content in the coal and the size of distillation receiver-tube chosen) is accurately weighed to \pm 0.1 gram. This sample could be larger than 1/4-inch by 0 if. a slightly longer distillation time is allowed. Preliminary air drying, grinding of the sample to minus-20- or minus-60-mesh, and subsequent mixing of the ground material are unnecessary steps. The A.S.T.M. sampling procedure is adhered to with regard to sampling at the source and sampling of the material to be tested at the laboratory site.

The sample is introduced into a $500-\mathrm{ml}$. round-bottom flask, and just enough xylol is added to cover the sample. An excess of xylol should be avoided since the volume of xylol used in rinsing and swabbing becomes appreciable. The flask is connected by ground glass"joints to a Stark-Dean type distilling tube, $\underline{20}$ / which is connected to a vertical Liebig type condenser. Enough xylol is added through the condenser to fill the distilling receiver tube. The distillation proceeds for 2 to 3 hours, using a hemispherical electric heating mantle; the voltage input is closely regulated by an autotransformer to prevent overheating and subsequent bumping. To prevent condensation of atmospheric moisture on the inner condenser tube, particularly during humid weather. when the condenser cooling water temperature is below the dew point, a cotton plug is inserted at the top of the condenser to block excessive air circulation.

When about 90 to 95 percent of the water has been distilled over into the moisture receiver tube, as evidenced by the clearing of the xylol fraction, the condenser should be rinsed with xylol and swabbed down with a neoprene rubber-washer swab. Complete clearing of the xylol fraction in the moisture tube and a lack of water droplets with each successive swabbing indicates that the distillation is finished. The time required for a single xylol distillation is 2 to 3 hours. The heating is discontinued, and the condenser is swabbed again for any adhering water droplets and rinsed with xylol. The volume of water read directly from the calibrated moisture tube, at room temperature, after complete settling and clearing, is considered the weight of the water observed. To calculate the percentage of moisture in the sample of coal, the weight of the water observed is divided by the weight of the coal sample, and the result is multiplied by 100 .

\section{A.S.T.M. and Bureau of Mines Method for Moisture Determination}

The test, in essence, is the drying of a sample of coal under controlled conditions and" the indirect determination of moisture by loss in weight of sample. If a 1.0000 -gram sample of coal is taken for analysis, the loss in weight, when multiplied by 100 , is taken to mean the percentage of moisture.

Briefly, a 1 -gram sample of minus- 60-mesh coal is dried for 1 hour in a constant temperature oven at $105^{\circ} \mathrm{C}$. through which a current of preheated air dried over sulfuric acid is passed. If minus-20-mesh coal is used, the conditions of the test change; a larger sample ( 5 grams) is used, and the time is extended to $1-1 / 2$ hours. At the end of the drying period, the sample is taken from the oven and cooled in a desiccator over concentrated sulfuric acid.

\section{Vacuum-Oven Method}

As an alternate oven-drying method for coals susceptible to oxidation, the vacuumoven procedure was introduced. The technique used here is similar in many respects to

20/ Dean, E. W., and Stark, D. D., Determination of Water in Petroleum and other Organic Emulsions: Jour. Ind. Eng. Chem., vol. 12, 1920, p. 486. 
the method recommended by the British Engineer Standards Association (1931). 2 ll In the main, the test consists of drying a minus-60-mesh sample of coal in a vacuum of 40 to $50 \mathrm{~cm}$. Hg at $14^{\circ}$ to $110^{\circ} \mathrm{C}$. . for $\mathrm{L}$ hour. The dried sample is cooled in a desiccator over concentrated sulfuric acid and weighed. The percentage of moisture in the coal sample is calculated by dividing the loss in weight of sample by the initial weight and that result is multiplied by 100 .

\section{ANALYTPICAL RESULTS}

The comparative study of the four methods of moisture determination in coal involved six coals representative of the types found in the Western States. The analytical history of these coils is given in table 2. As can be noted, the moisture range spreads from a low of 8.8 percent (measured by A.S.T.M. procedure) shown by Harris coal to a high value of 38.1 percent (determined by A.S.T.M. methods) given by Dakota Star lignite. Two forms of Wyodak coal were tested; the first was a fresh sample of. Wyodak, and the second was a sample of the steam-dried coal. Total moistures of 26.8 and 9.2 percent, respectively (A.S.T.M. figures), were recorded for these 2 coals. In addition to Dakota Star lignite, a Texas lignite was tested for its moisture content. The Texas lignite gave a moisture value of 34.4 percent when tested by A.S.T.M. standard method.

The fact that the oven-drying techriques now in use were unable to measure the total potentially measurable. water in coal became apparent early in the study. Inspection of table 3 will show that, wi.th coals of 10 percent molsture or less, the moisture-oven A.S.T.M. technique gave an average reading of 6 percent less than the average recorded for either the xylol distillation or Schoch oil-dehydration methods. Effectively, the A.S.T.M. method measures 94 percent of the water in a 10-percentmoisture coal. With coals showing a moisture content of about 20 percent, the average reading given by the A.S.T.M. method was approximately. 5.5 percent lower than that given by the xylol distillation method or by the Schoch oil-dehydration technique. In coals having moisture values of approximately 30 percent, the total water, measured by the A.S.T.M. procedure, was only 96 percent of the total measurable water by xylol: distiliation method. Coals showing about 40 percent moisture content by xylol method gave only 95 percent of that value when tested by the A.S.T.M. method.

For the same coals, the vacuum-oven technique gave lower values than either the A.S.T.M. molsture oven or the distillation methods cited. With coals having 10.0 percent moisture, the vacuum oven gave average readings that were 3 to 4 : percent lower than those obtained by the A.S.T.M. method. In determining the moisture content of coals in the neighborhood of 20 percent, the results obtained by the vacuumoven technique were, on an average, 2.3 percent lower than the results obtained by the A.S.T.M. method. With respect to the xylol distillation method, the vacuum oven determined 88 percent of the measurable water in a 10-percent-moisture coal and 94 percent of the measurable water in a coal whose moisture value is approximately 20 percent. ' When compared to the Schoch ofl-dehydration procedure, the vacuum oven effectively measures 88 percent of the measurable water in a coal whose moisture value is about 20.5 percent. Since the drying-oven techniques are empirical in nature, fixed conditions must be observed.. The loss in weight of sample with such procedures is assumed to be due entirely to moisture loss"; however, if the conditions are changed, the weight-loss figure changes, and it follows that a given set of ovendrying determinations, although precise, does not necessarily represent the total measurable moisture.

2I] See footnote 14 . 
TABIE 2. - Identification and analyses of coals studied in the comparison of methods for determining moisture in coal.

\begin{tabular}{|c|c|c|c|c|c|c|}
\hline $\begin{array}{l}\text { Coal } \\
\text { No. }\end{array}$ & Mine & Location & Rank & Condition & $\begin{array}{l}\text { Denver } \\
\text { Lab. No. }\end{array}$ & $\begin{array}{c}\text { Pgh. } \\
\text { Lab. No. }\end{array}$ \\
\hline $\begin{array}{ll}\text { MS } & 1 \\
\text { MS } & 2 \\
\text { MS } & 3 \\
\text { MS } & 4 \\
\text { MS } & 5 \\
\text { MS } & 6\end{array}$ & $\begin{array}{l}\text { Harris } \\
\text { Wyodak } \\
\text { Caprock } \\
\text { Wyodak } \\
\text { Sandow } \\
\text { Dakota Star }\end{array}$ & $\begin{array}{l}\text { Mount Harris, Routt County, Colo. } \\
\text { Gillette, Campbell County, Wyo: } \\
\text { Arvada, Jefferson County, Colo. } \\
\text { Gillette, Campbell County, Wyo. } \\
\text { Rockdale, Milam County, Tex. } \\
\text { Hazen, Mercer County, N. Dak. }\end{array}$ & $\begin{array}{l}\text { Hvcb } \\
\text { Subc } \\
\text { Subb } \\
\text { Subc } \\
\text { Lig. } \\
\text { do. }\end{array}$ & $\begin{array}{l}\text { Fresh } \\
\text { Steam-dried } \\
\text { Fresh } \\
\text { do. } \\
\text { do. } \\
\text { do. }\end{array}$ & $\begin{array}{l}191 \\
189-1 \\
172-8 \\
188-2 \\
192 \\
183\end{array}$ & $\begin{array}{l}C-71214 \\
C-70627 \\
C-69508 \\
C-67164 \\
C-71569 \\
C-68689\end{array}$ \\
\hline
\end{tabular}

\begin{tabular}{|c|c|c|c|c|c|c|c|c|c|c|c|c|}
\hline \multirow{3}{*}{$\begin{array}{l}\text { Coal } \\
\text { No. }\end{array}$} & \multicolumn{3}{|c|}{ Proximate, percent } & & & & & & & \multirow{3}{*}{$\begin{array}{c}\text { Alr-dry } \\
\text { loss, } \\
\text { percent }\end{array}$} & \multirow{3}{*}{$\begin{array}{c}\text { British } \\
\text { thermal } \\
\text { units }\end{array}$} & \multirow{3}{*}{$\begin{array}{c}\text { Soft } \\
\text { temp. of } \\
\text { ash, of. }\end{array}$} \\
\hline & \multirow[b]{2}{*}{ Moisture } & \multirow{2}{*}{$\begin{array}{c}\text { Volatile } \\
\text { matter }\end{array}$} & \multirow{2}{*}{$\begin{array}{l}\text { Fixed } \\
\text { carbon }\end{array}$} & \multicolumn{6}{|c|}{ Untimate, percent } & & & \\
\hline & & & & Ash. & Sulfur. & Hýdrogen & Carbon & Nitrogen & Oxygen & & & \\
\hline MS 1 & $\frac{1}{\frac{2}{3}} / 8.8$ & $\begin{array}{l}38.7 \\
42.4 \\
46.0\end{array}$ & $\begin{array}{l}45.5 \\
49.9 \\
54.0\end{array}$ & $\begin{array}{l}7.0 \\
7.7\end{array}$ & $\begin{array}{r}0.4 \\
.5 \\
.5\end{array}$ & $\begin{array}{l}5.6 \\
5.1 \\
5.5\end{array}$ & $\begin{array}{l}66.5 \\
72.9 \\
79.0\end{array}$ & $\begin{array}{l}1.6 \\
1.7 \\
1.9\end{array}$ & $\begin{array}{l}18.9 \\
12.1 \\
13.1\end{array}$ & 2.4 & $\begin{array}{l}11,750 \\
12,880 \\
13,950\end{array}$ & 2,910 \\
\hline MS 2 & $\frac{1}{\frac{2}{3}} / 9.2$ & $\begin{array}{l}39.9 \\
44.0 \\
49.1\end{array}$ & $\begin{array}{l}41.4 \\
45.5 \\
50.9\end{array}$ & $\begin{array}{r}9.5 \\
10.5\end{array}$ & $\begin{array}{l}.8 \\
.8 \\
.9\end{array}$ & $\begin{array}{l}5.5 \\
4.9 \\
5.5\end{array}$ & $\begin{array}{l}60.6 \\
66.7 \\
74.6\end{array}$ & $\begin{array}{r}.8 \\
.9 \\
1.0\end{array}$ & $\begin{array}{l}22.8 \\
16.2 \\
18.0\end{array}$ & 3.3 & $\begin{array}{l}10,540 \\
11,610 \\
12,970\end{array}$ & 2,340 \\
\hline MS 3 & $\frac{1}{2} / 21 \cdot 5$ & $\begin{array}{l}33.8 \\
43.0 \\
46.2\end{array}$ & $\begin{array}{l}39.3 \\
50.1 \\
53.8\end{array}$ & $\begin{array}{l}5.4 \\
6.9\end{array}$ & $\begin{array}{l}.7 \\
.9 \\
.9\end{array}$ & $\begin{array}{l}6.0 \\
4.6 \\
4.9\end{array}$ & $\begin{array}{l}54.1 \\
69.0 \\
7: 4.1\end{array}$ & $\begin{array}{r}.7 \\
.9 \\
1.0\end{array}$ & $\begin{array}{l}33.1 \\
17.7 \\
19.1\end{array}$ & 12.7 & $\begin{array}{r}9,250 \\
11,970 \\
12,660\end{array}$ & 2,060 \\
\hline MS 4 & $\frac{1}{\frac{2}{3}} / 26.8$ & $\begin{array}{l}32.0 \\
43.6 \\
51.2\end{array}$ & $\begin{array}{l}30.3 \\
41.6 \\
48.8\end{array}$ & $\begin{array}{l}10.9 \\
14.8\end{array}$ & $\begin{array}{l}1.0 \\
1.3 \\
1.6\end{array}$ & $\begin{array}{l}6.4 \\
4.7 \\
5.5\end{array}$ & $\begin{array}{l}45.8 \\
62.6 \\
73.5\end{array}$ & $\begin{array}{l}1.1 \\
1.5 \\
1.7\end{array}$ & $\begin{array}{l}34.8 \\
15.1 \\
17.7\end{array}$ & 19.3 & $\begin{array}{r}8,020 \\
10,960 \\
12,870\end{array}$ & 2,440 \\
\hline MS 5 & $\frac{\frac{1}{2} / 3^{34} \cdot 4}{3} /{ }^{3}$ & $\begin{array}{l}28.2 \\
43.0 \\
50.5\end{array}$ & $\begin{array}{l}27.6 \\
42.1 \\
49.5\end{array}$ & $\begin{array}{r}9.8 \\
14.9\end{array}$ & $\begin{array}{l}.8 \\
1.2 \\
1.4\end{array}$ & $\begin{array}{l}6.9 \\
4.6 \\
5.4\end{array}$ & $\begin{array}{l}40.9 \\
62.3 \\
73.2\end{array}$ & $\begin{array}{l}.8 \\
1.3 \\
1.5\end{array}$ & $\begin{array}{l}40.8 \\
15.7 \\
18.5\end{array}$ & 26.8 & $\begin{array}{r}7,100 \\
10,820 \\
12,710\end{array}$ & 2,380 \\
\hline MS 6 & $\frac{1}{2} / 38.1$ & $\begin{array}{l}26.8 \\
43.4 \\
48.2\end{array}$ & $\begin{array}{l}29.0 \\
46.7 \\
51.8\end{array}$ & $\begin{array}{l}6.1 \\
9.9\end{array}$ & $\begin{array}{r}.9 \\
1.4 \\
1.6\end{array}$ & $\begin{array}{l}6.9 \\
4.3 \\
4.8\end{array}$ & $\begin{array}{l}40.4 \\
65.2 \\
72.4\end{array}$ & $\begin{array}{r}.6 \\
.9 \\
1.0\end{array}$ & $\begin{array}{l}45.1 \\
18.3 \\
20.2\end{array}$ & 30.5 & $\begin{array}{r}6,760 \\
10,920 \\
12,130\end{array}$ & 2,460 \\
\hline
\end{tabular}

I) Analyses calculated on the as-received basis.

2) Analyses calculated on the moisture-free basis.

3/. Analyses calculated on the moisture- and ash-free basis. 
TABLE 3. - Comparison of methods for determining moisture in coal I/

\begin{tabular}{|c|c|c|c|c|c|c|c|c|c|c|}
\hline ethod Condition & \multicolumn{2}{|c|}{$\begin{array}{l}\ddots \because \because \\
1 / 4-\text { Inch } x: 0\end{array}$} & \multicolumn{2}{|c|}{$\begin{array}{c}\text { Fresh } \\
-20-\text { mesh }\end{array}$} & \multicolumn{2}{|c|}{ 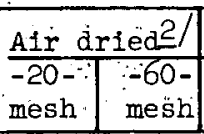 } & \multicolumn{3}{|c|}{$\frac{\text { Air dried } 3 /}{-60-\text { mesh }}$} & Average \\
\hline & & & & & & & & & & \\
\hline Isture oven 67 & $\begin{array}{l}9 \\
10\end{array}$ & $\begin{array}{l}- \\
- \\
10.3 \\
10.2\end{array}$ & - & $\begin{array}{r}-7 \\
-70.4 \\
10.1\end{array}$ & $\begin{array}{l}=9 . \\
9 . \\
10 .\end{array}$ & $\begin{array}{r}9.6 \\
9.4 \\
10.8 \\
10.2\end{array}$ & $\mid$\begin{tabular}{c}
9.5 \\
9.3 \\
\hdashline \\
\hdashline
\end{tabular} & $\begin{array}{l}9 . \\
9 . \\
-\end{array}$ & $\begin{array}{l}10 \\
9 \\
-\end{array}$ & $\begin{array}{l}10.2 \\
10.2\end{array}$ \\
\hline
\end{tabular}

Moisture in steam-drjed Wyodak coal, percent

\begin{tabular}{|c|c|c|c|c|c|c|c|c|c|c|}
\hline $\begin{array}{l}\text { A.S.T.M. molsture oven } 6 / \\
\text { Vacuum oven } 6 / \ldots \ldots . . . . . \\
\text { Xylol distillation } \ldots . . . \\
\text { Schoch ioll dehydration... }\end{array}$ & $\begin{array}{l}- \\
10.0 \\
10.4\end{array}$ & $\begin{array}{c}- \\
10.5 \\
10.2\end{array}$ & $\begin{array}{c}- \\
- \\
1.0 .8 \\
1.0 .3\end{array}$ & $\begin{array}{r}- \\
10.6 \\
10.5\end{array}$ & $\begin{array}{l}9.1 \\
8.2 \\
10.2 \\
10.9\end{array}$ & $\begin{array}{r}9.6 \\
9.1 \\
10.5 \\
10.8\end{array}$ & $\begin{array}{c}9.4 \\
9.1 \\
- \\
-\end{array}$ & $\begin{array}{l}9.9 \\
9.1 \\
- \\
-\end{array}$ & $\mid \begin{array}{c}10.0 \\
9.1 \\
- \\
-\end{array}$ & $\begin{array}{r}9.6 \\
8.9 \\
10.4 \\
10.5\end{array}$ \\
\hline
\end{tabular}

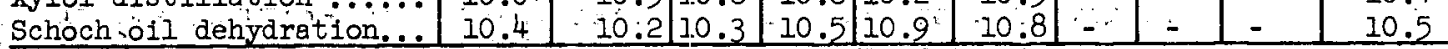

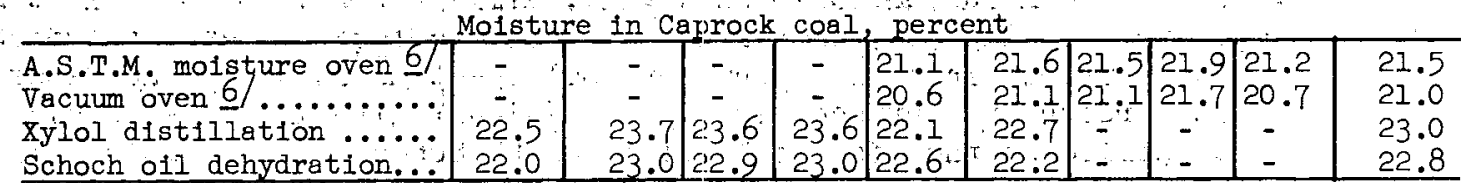

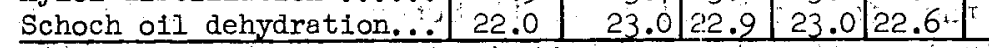

Moisture in Wrodak coal, percent

\begin{tabular}{|c|c|c|c|c|c|c|c|c|c|c|}
\hline 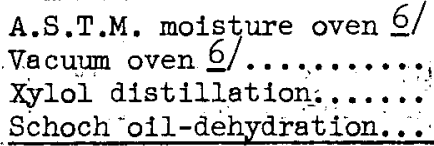 & $\begin{array}{l}- \\
28.1 \\
28.1\end{array}$ & $\begin{array}{l}- \\
2 \overrightarrow{8} \cdot 3 \\
28: 1\end{array}$ & $\begin{array}{r}- \\
2.8 .5 \\
2.7 .4\end{array}$ & $\begin{array}{r}- \\
2 \overline{8} .5 \\
27.5\end{array}$ & $\begin{array}{l}26.9 \\
\bar{i} .1 \\
28.1 \\
28.5\end{array}$ & $\begin{array}{l}27.5 \\
27: .7 \\
28: 7 \\
28: 0\end{array}$ & $\mid \begin{array}{l}27 \cdot 5 \\
27 \cdot 3 \\
-\end{array}$ & 27.3 & $\begin{array}{c}\overline{2} .7 \\
-\end{array}$ & $\begin{array}{l}21.3 \\
27.1 \\
28.4 \\
27.9\end{array}$ \\
\hline
\end{tabular}

Schoch oll-dehydration.... 28.1 Moisture in Sancow lignite, percent.

\begin{tabular}{|l|l|l|l|l|l|l|l|l|l|l|l|}
\hline A.S.T.M. moisture oven 6/ & - & - & - & - & 3.4 .6 & 35.0 & 34.4 & 35.3 & 35.2 & 34.9 \\
Vacuum oven 6/......... & - & - & - & - & 34.0 & 34.3 & 33.8 & 34.6 & 34.7 & 34.3 \\
Xylol distiliation $\ldots .9 .9$ & 36.0 & 36.3 & 36.0 & 36.4 & 35.7 & 35.8 & - & - & - & 36.0 \\
Schoch oll dehydration... & 36.0 & 36.2 & 35.1 & 35.2 & 36.0 & 36.0 & - & - & - & 35.8 \\
\hline
\end{tabular}

Moisture in Dakota Star lignite, percent

\begin{tabular}{|c|c|c|c|c|c|c|c|c|c|c|}
\hline $\begin{array}{l}\text { A.S.T.M. moisture oven } 6 / \\
\text { Vacuum oven } 6 . \ldots \ldots \ldots \\
\text { Xylol distillation........ } \\
\text { Schoch oil dehydration. }\end{array}$ & $\begin{array}{c}-\cdots \\
-: \\
39.1 \\
39.4\end{array}$ & $\begin{array}{l}-1.5 \\
39.4\end{array}$ & $\begin{array}{c}-\cdots \\
- \\
40.2 \\
38.8\end{array}$ & $\begin{array}{c}-2 \\
-1 \\
39.6 \\
38.6\end{array}$ & $\begin{array}{l}37.5 \\
37: 0 \\
39.4 \\
39.2\end{array}$ & $\begin{array}{l}38.2 \\
37.9 \\
39.2 \\
39.2\end{array}$ & $\begin{array}{l}38.4 \\
38.0 \\
- \\
-\end{array}$ & $\begin{array}{l}37 \cdot 7 \\
37: \cdot 3 \\
-.: \\
-\end{array}$ & $\begin{array}{l}37 \cdot 2 \\
36.2 \\
- \\
-\end{array}$ & $\begin{array}{r}37.8 \\
37.3 \\
39.7 \\
39.1\end{array}$ \\
\hline
\end{tabular}

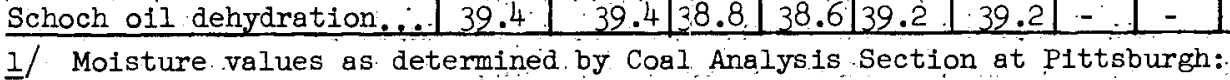

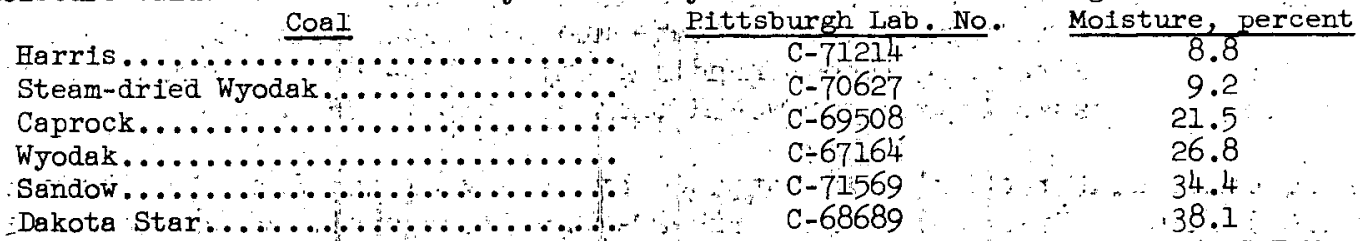

2/. Approximately $3 \mathrm{lb}$ of fresh coal, $1 / 4-x 0$-inch, air-dried according to A.S.T.M. Standard D-271-48, Section 4.-A1r-dry loss: Harris = 6.0 percent. steam-dried Wyodak $=4.5$ percent; Caprock $=14.7$ percent; Wyodak $=20.9$ percent; Sandow $=$ "29.8 percent; and Dakota Star $=31.1$ percent."

3/ Each value given is average of three individual determinations:

4/ 100-gram samples of fresh, coal dried at $104^{\circ}-110^{\circ} \mathrm{C}$. in electric'drying oven to approximately the same percent loss as in $2 /$ for each coal:

5/ 1/4- x 0-inch fresh coal. Air-dry loss : Harris, (a) $=5.3$ percent; (b) $=4.4$ percent;

Steam-dried Wyodak, (a) = 4.3 percent; (b) $=5.3$ percent;

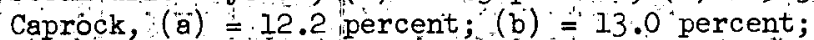

Wyodak - Sample II, $(a)=24.3$ percent; $(b)=24.7$ percent;

Sandow, $(a)=24.8$ percent; $(b)=29.2$ percent;

Dakota Star, $(\mathrm{a})=27.9$ percent; $(\mathrm{b})=26.9$ percent.

6) Minus-20-mesh fresh coal.

Air-dry loss: Harris, $(c)=6.8$ percent; steam-dried Wyodak $(c)=6.7$ percent; Caprock $(c)=11.6$ percent; Wyodak - Sample II $(c)=22.6$ percent; Sandow $(\mathrm{c})=31.6$ percent; Dakota Star $(\mathrm{c})=27.2$ percent. 
Table 4 summarizes the data on the comparison of oven-drying methods as moisturedetermining techniques. It is seen that the vacuum-oven technique is generally about .2 percent lower than A.S.T.M. procedure. Both methods give somewhat parallel results, as shown in figure 3. Moreover, it is shown here that treatment and handling of the sample before the actual test have some influence "on the final result. Air-dried samples ground to minus-20-mesh gave results 1 to 2 percent lower than those ground to minus-60-mesh with either method. Oven-dried samples ( $1 / 4$-inch by 0 ) ground to minus60-mesh gave results that were generally equal to or slightly higher than those given by a minus-20-mesh sample that was ground to minus-60-mesh.

The accuracy that may be obtained by the oven-drying methods is limited-by the conditions of the test. To a smaller degree, the accuracy obtained by the Schoch oildehydration method is governed by the same factors. Time, temperature, and skill in manipulation, which in the main control oven drying, delimit the value of this test. The limiting temperature of $225^{\circ} \mathrm{C}$. , when reached at an accelerated rate, introduces an easily foreseeable error. In a given lump of coal the time in which the water from the interior can reach the surface becomes significant with increase in size. When the method is applied to the size coal specified by Schoch, the question arises whether the distillation should be continued for an additional time to introduce: a time safety factor.

Although all the free water in a sample of coal is removed at $225^{\circ} \mathrm{C}$. by the Schoch procedure, additional heating beyond this point brings about chemical decomposition of coal substance with the formation of water. This trend is illustrated in figure 4, where Caprock and Dakota. Star coals exhibit a chemical breakdown at about $260^{\circ}$ and $250^{\circ}$. C., respectively.

The xylol distillation and the Schoch oil dehydration methods may be compared from data shown in table 5. The results from the xylol distillation and Schoch oildehydration determinations parallel closely. These two direct methods show an apparent loss in moisture on tests. using the finer size coal, probably as a result of excessive handling owing to introduction of an air-drying step. Air drying invariably will introduce a weight error. Since no significant data can be obtained from air-drying-loss figures, this step could be simplified by the introduction of .a direct moisture-determin'ing method that would enable the analyst to determine the as received, and if necessary for proximate and ultimate analyses, the stabilized air-dried moisture directly. without handling any weight-loss figures. Conversion from one moisture basis to another would then be simplified.

More concordant results were obtained by the xylol and Schoch methods on tests using 1/4-inch by 0 fresh coal and minus-20-mesh fresh coal. With most coals the amount of water that could be obtained by the xylol technique was slightly more than that measured by the Schoch method. If the distillation methods are compared with the A.S.T.M. moisture oven technique, it is seen that, for all coals tested, the A.S.T.M. method gave the lower result. It is particularly significant that the A.S.T.M. method showed a deviation of about minus. 1.1, when compared to the xylol distillation method, for all coals tested.

To determine the role of particle size on moisture determination, a series of tests on $1 / 2-$ by $1 / 4$-inch was initiated. Fifteen pounds of fresh Wyodak coal passing a 0.525 -inch screen and retained on a 0.263 -inch screen was used in this study. 


\begin{tabular}{|c|c|c|c|c|c|}
\hline Method & A.S.T.M. D-2 & -48 Section 4 & \multicolumn{3}{|c|}{ Electric Drying Oven af $104^{\circ}-110^{\circ} \mathrm{C}$} \\
\hline Cool & \multicolumn{2}{|c|}{ Fresh } & \multicolumn{2}{|c|}{ Fresh } & Fresh \\
\hline Initial size & \multicolumn{2}{|c|}{$1 / 4 \times 0$-inch } & \multicolumn{2}{|c|}{$1 / 4 \times 0-$ inch } & Possing No. 20 \\
\hline Ground to & Passing No. 20 & Possing No. 60 & Possing No. 60 & Possing No. 60 & Passing No. 60 \\
\hline
\end{tabular}

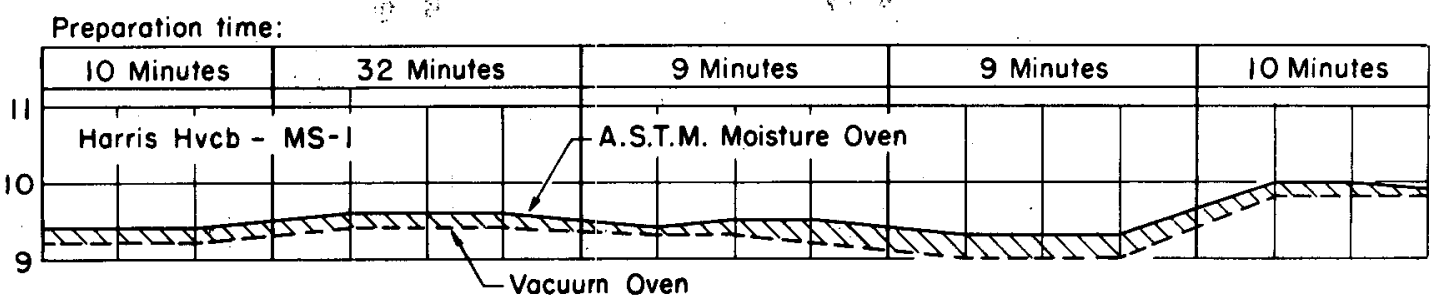

\section{Preporation time:}

\begin{tabular}{|c|c|c|c|c|}
\hline 12 Minutes & 37 Minutes & 8 Minutes & 8 Minutes & 8 Minutes \\
\cline { 2 - 5 } & Steam dried Wyodak & Subc-MS-2 & A.S.T.M. Moisture Oven & \\
\hline
\end{tabular}
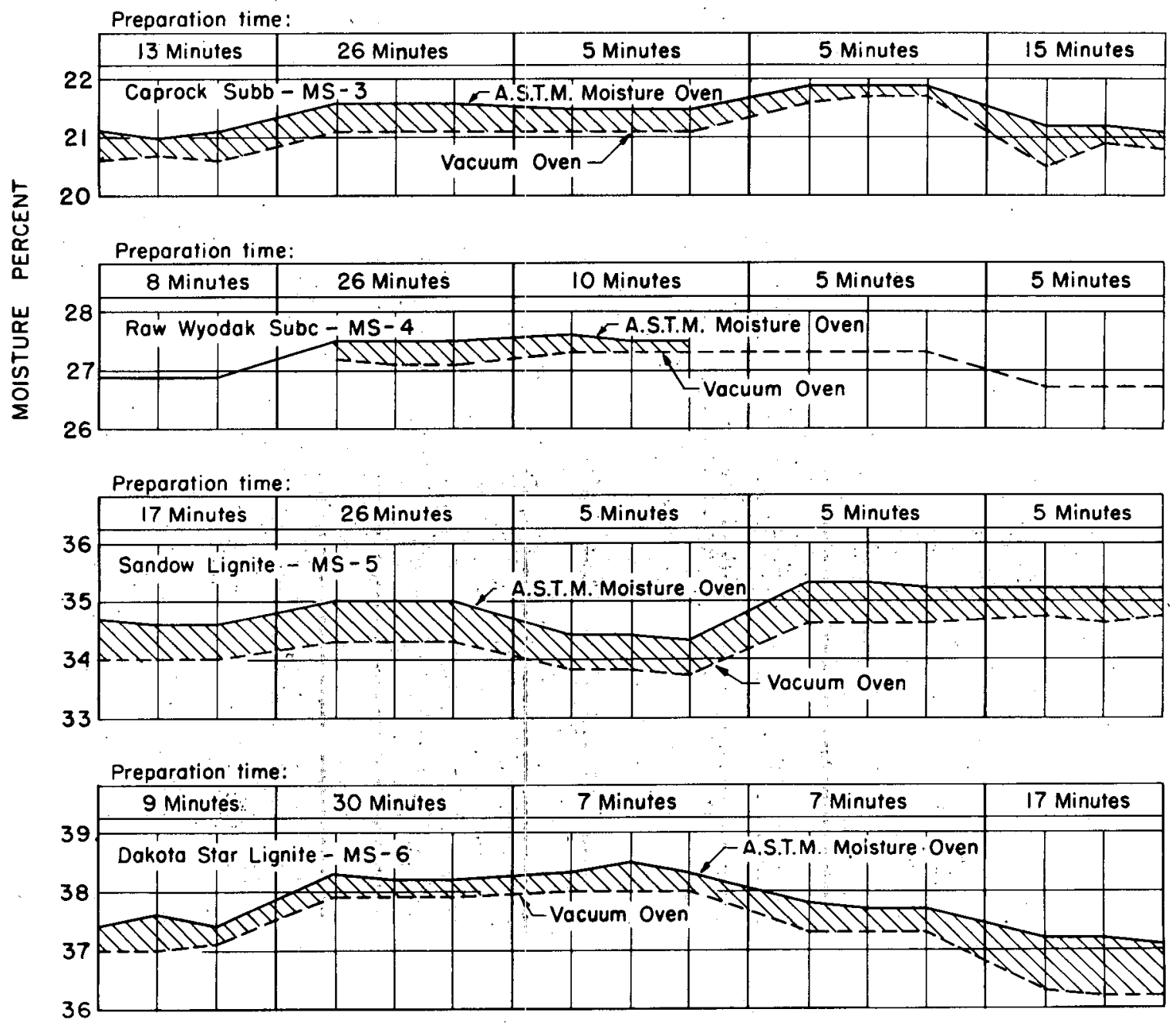

Figure 3. - Comparison of oven-drying methods. 


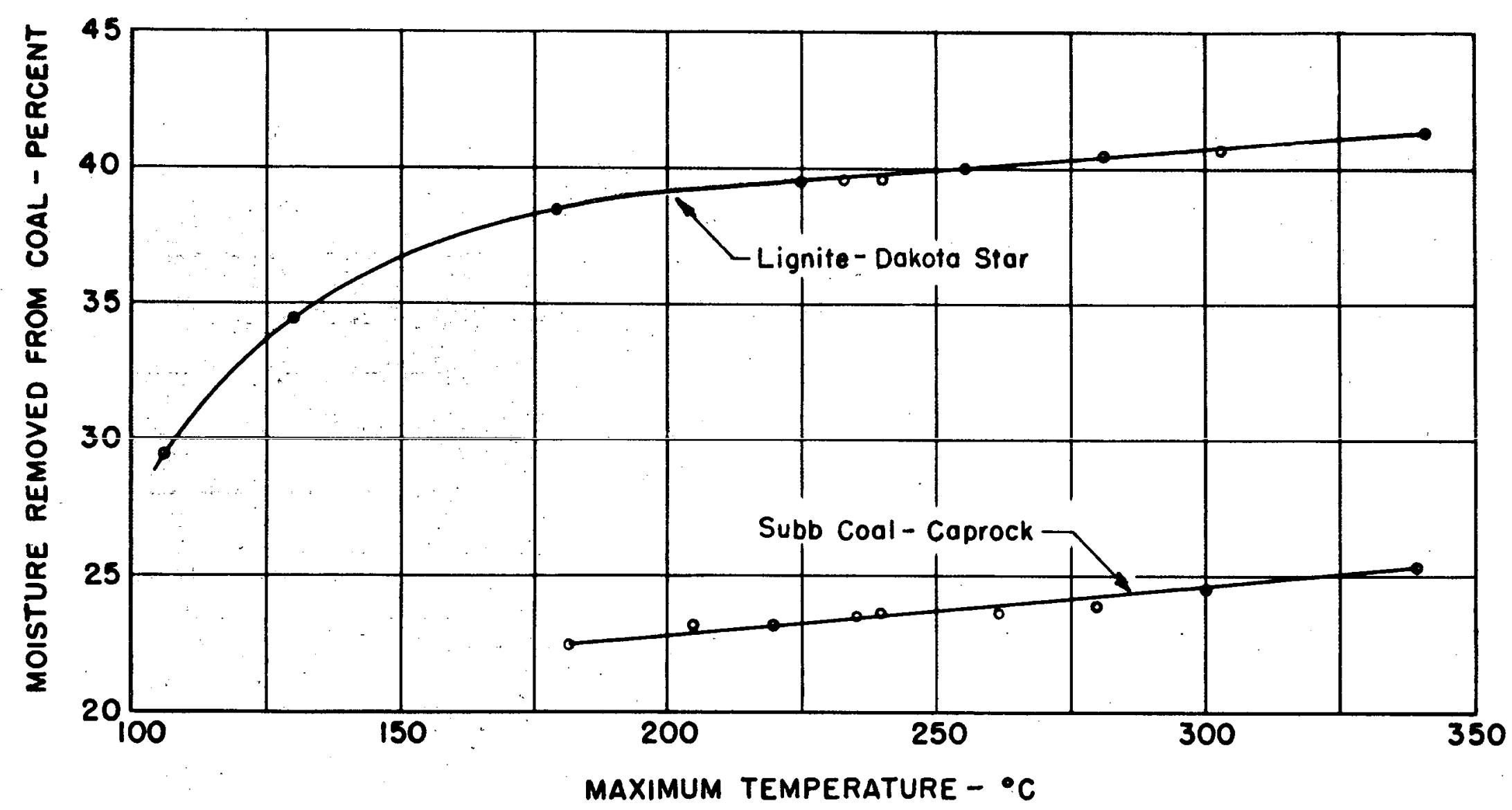

Figure 4. - Influence of temperature on extent of moisture removed by Schoch oil-dehydration method. 
TABLE 4. - Comparison of oven-drying methods for determining moisture in coal

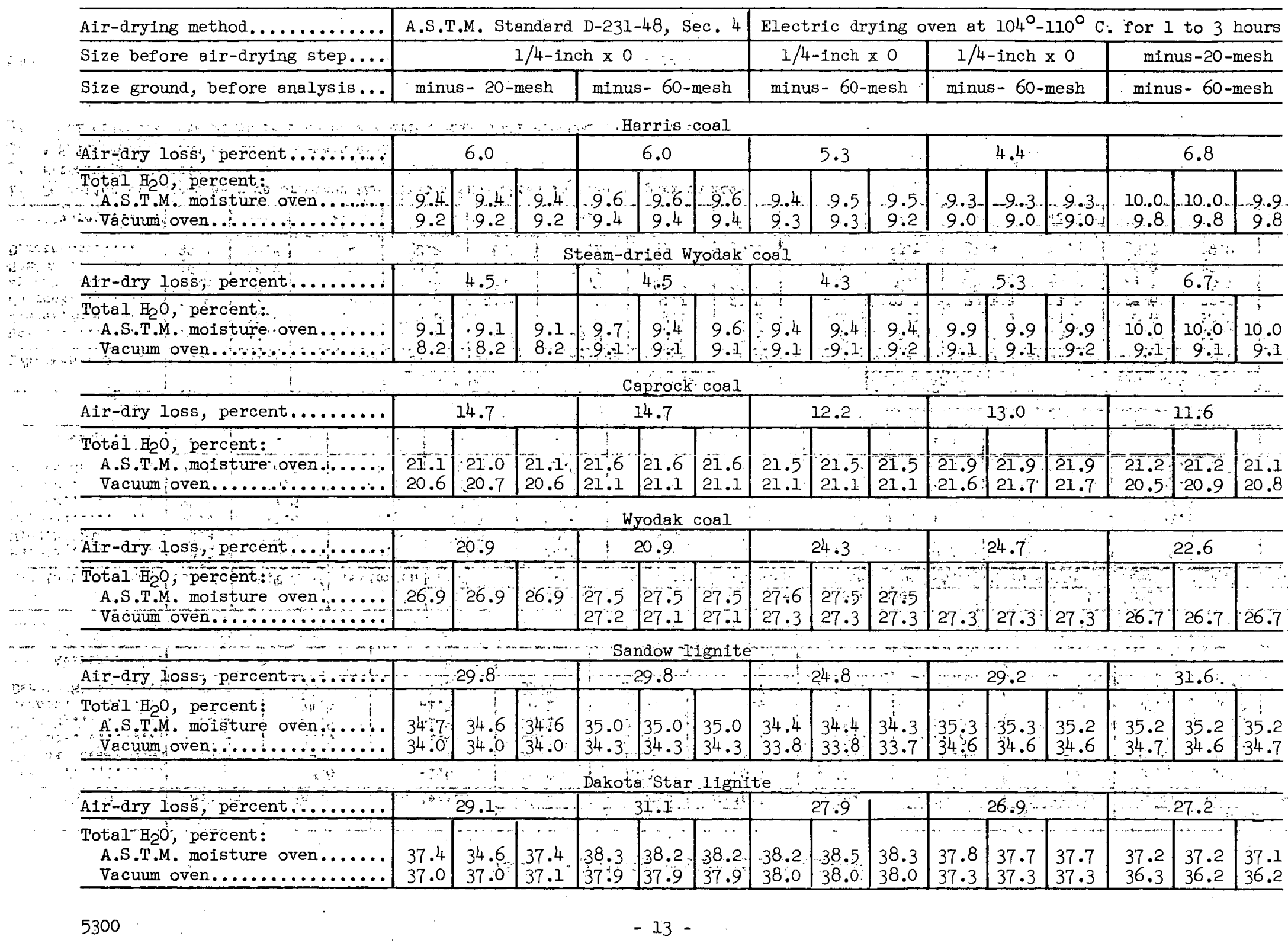


TABLE 5. - Deviation between various methods $1 /$

\begin{tabular}{|c|c|c|c|c|c|c|c|c|c|c|c|c|}
\hline \multirow[b]{2}{*}{$1 / 4$-inch $\times 0$ coal } & \multirow{2}{*}{ Schoch } & \multirow[b]{2}{*}{$\mathrm{Pgh} . \dot{2}$} & \multirow{2}{*}{ Deviation } & \multicolumn{3}{|c|}{ Schoch } & \multicolumn{3}{|c|}{ Schoch - air dried } & \multicolumn{3}{|c|}{ Minus-20-mesh } \\
\hline & & & & $1 / 4^{\prime \prime} \times 0$ & -20 -mesh & Deviation & -20 -mesh & -60 -mesh & Deviation & Schoch & Xylol & Deviation \\
\hline 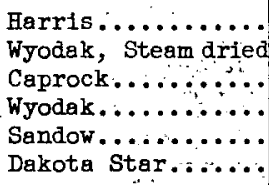 & $\begin{array}{r}10.2 \\
10.3 \\
22.9 \\
28.1 \\
-36.1 \\
39.4\end{array}$ & $\begin{array}{r}8.8 \\
9.2 \\
21.5 \\
26.8 \\
34.4 \\
.38 .1\end{array}$ & $\begin{array}{l}-1.4 \\
-1.1 \\
-1.4 \\
-1.3 \\
-1.7 \\
-1.3\end{array}$ & $\begin{array}{l}10.2 \\
10.3 \\
22.9 \\
28.1 \\
36.1 \\
39.4\end{array}$ & $\begin{array}{l}10.1 \\
10.4 \\
23.0 \\
27.5 \\
35.2 \\
38.7\end{array}$ & $\begin{array}{l}-0.1 \\
+.1 \\
+.1 \\
-.6 \\
-.9 \\
-. .7\end{array}$ & $\begin{array}{l}10.2 \\
10.9 \\
22.6 \\
28.5 \\
36.0 \\
39.2\end{array}$ & $\begin{array}{r}10.2 \\
: 10.8 \\
22.2 \\
28.0 \\
36.0 \\
39.2 \\
\end{array}$ & $\begin{array}{r}0.0 \\
-.1 \\
-.4 \\
0.5 \\
.0 \\
.0\end{array}$ & $\begin{array}{l}10.1 \\
10.4 \\
23.0 \\
27.5 \\
35.2 \\
38.7\end{array}$ & $\begin{array}{l}10.5 \\
10.7 \\
23.6 \\
28.5 \\
36.2 \\
39.9\end{array}$ & $\begin{array}{r}+0.4 \\
+.3 \\
+.6 \\
+1.0 \\
+1.0 \\
+1.2\end{array}$ \\
\hline Average....... & $\cdots$ & ... & -1.4 & - & $-\because$ & -.4 & - & - & -.2 & - & - & +.8 \\
\hline
\end{tabular}

\begin{tabular}{|c|c|c|c|c|c|c|c|c|c|c|c|c|}
\hline \multirow[b]{2}{*}{$1 / 4-$ inch $\times 0$ coal } & \multirow{2}{*}{ Schoch } & \multirow{2}{*}{ A.S.T.M.3/ } & \multirow[b]{2}{*}{ Deviation } & \multicolumn{3}{|c|}{ Xylol } & \multicolumn{3}{|c|}{ zylol - air dried } & \multicolumn{2}{|c|}{ A.S.T.M. } & \multirow[b]{2}{*}{ Deviation } \\
\hline & & & & $1 / 4^{\prime \prime} \times 0$ & -20 -mesh & Deviation & -20 -mesh & $-60-\operatorname{mesh}$ & Deviation & minus-20-mesh & minus -60 -mesh 4 & \\
\hline 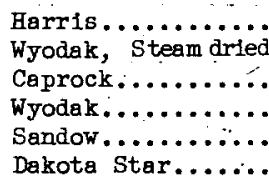 & $\begin{array}{l}10.2 \\
10.3 \\
22.9 \\
28.1 \\
36.1 \\
39.4\end{array}$ & $\begin{array}{r}9.6 \\
9.6 \\
21.6 \\
27.5 \\
35.0 \\
38.2\end{array}$ & $\begin{array}{r}-0.6 \\
-.7 \\
-1.3 \\
-.6 \\
-1.1 \\
-1.2\end{array}$ & $\begin{array}{l}10.1 \\
10.3 \\
23.1 \\
28.2 \\
36.2 \\
39.8\end{array}$ & $\begin{array}{l}10.5 \\
10.7 \\
23.6 \\
28.5 \\
36.2 \\
39.9\end{array}$ & $\begin{array}{r}+0.4 \\
+.4 \\
+.5 \\
+.3 \\
.0 \\
+.1\end{array}$ & $\begin{array}{l}10.3 \\
10.2 \\
22.1 \\
28.1 \\
35.7 \\
39.4\end{array}$ & $\begin{array}{l}10.8 \\
10.5 \\
22.7 \\
28.7 \\
35.8 \\
39.2\end{array}$ & $\begin{array}{r}+0.5 \\
+.3 \\
+.6 \\
+.6 \\
+.1 \\
-.2\end{array}$ & $\begin{array}{r}9.4 \\
9.1 \\
21.1 \\
26.9 \\
34.6 \\
37.5\end{array}$ & $\begin{array}{r}9.6 \\
9.6 \\
21.6 \\
27.5 \\
35.0 \\
38.0\end{array}$ & $\begin{array}{r}+0.2 \\
+.5 \\
+.5 \\
+.6 \\
+.4 \\
+.7\end{array}$ \\
\hline Average..... & - & - & -.9 & - & - & +.3 & - & - & +.3 & - & - & +.5 \\
\hline
\end{tabular}

\begin{tabular}{|c|c|c|c|c|c|c|c|c|c|c|c|c|c|c|c|}
\hline \multirow[b]{2}{*}{$1 / 4-1$ nch $x \cdot 0 \cos 1$} & \multirow[b]{2}{*}{ Schoch } & \multirow[b]{2}{*}{ Xflol } & \multirow[b]{2}{*}{ Deviation } & \multicolumn{2}{|c|}{ A.S.T.M. } & \multirow[b]{2}{*}{ Deviation } & \multirow{2}{*}{ A.S.T.M. } & \multirow[b]{2}{*}{ Pgh .4 } & \multirow[b]{2}{*}{ Deviation } & \multicolumn{2}{|c|}{ minus -20 -mesh } & \multirow[b]{2}{*}{ Deviation } & \multicolumn{2}{|c|}{ minus-60-mesh } & \multirow[b]{2}{*}{ Deviation } \\
\hline & & & & -60 -mesh & Pgh.? & & & & & A.S.T.M. & xylol4 & & A.S.T.M. & xylo14] & \\
\hline 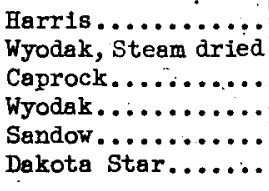 & $\begin{array}{l}10.2 \\
10.3 \\
22.9 \\
28.1 \\
36.1 \\
39.4\end{array}$ & $\begin{array}{l}10.1 \\
.10: 3 \\
23.1 \\
28.2 \\
36.2 \\
39.8 \\
\end{array}$ & $\begin{array}{r}-0.1 \\
.0 \\
+.2 \\
+.1 \\
+.1 \\
+.4\end{array}$ & $\begin{array}{r}9.6 \\
9.6 \\
21.6 \\
-27.5 \\
35.0 \\
38.2\end{array}$ & $\begin{array}{r}8.8 \\
9.2 \\
21.5 \\
26.8 \\
34.4 \\
38.1\end{array}$ & $\begin{array}{l}-0.8 \\
-.4 \\
-.1 \\
-.7 \\
-. .6 \\
-.1\end{array}$ & $\begin{array}{r}9.4 \\
9.1 \\
21.1 \\
26.9 \\
34.6 \\
37.5\end{array}$ & $\begin{array}{r}8.8 \\
9.2 \\
21.5 \\
26.8 \\
34.4 \\
38.1 \\
\end{array}$ & $\begin{array}{r}-0.6 \\
+.1 \\
+.4 \\
-.1 \\
-.2 \\
+.6\end{array}$ & $\begin{array}{r}9.4 \\
9.1 \\
21.1 \\
26.9 \\
34.6 \\
37.5 \\
\end{array}$ & $\begin{array}{l}10.3 \\
10.2 \\
22.1 \\
28.1 \\
35.7 \\
39.4\end{array}$ & $\begin{array}{l}+0.9 \\
+1.1 \\
+1.0 \\
+1.2 \\
+1.1 \\
+1.9\end{array}$ & $\begin{array}{r}9.6 \\
9.6 \\
21.6 \\
27.5 \\
35.0 \\
38.2\end{array}$ & $\begin{array}{l}10.8 \\
10.5 \\
22.7 \\
28.7 \\
35.8 \\
39.2\end{array}$ & $\begin{array}{l}+1.2 \\
+0.9 \\
+1.1 \\
+1.2 \\
+0.8 \\
+1.0\end{array}$ \\
\hline Average....... & - & - & +.1 & - & - & -.5 & - & - & .0 & - & $=$ & +1.2 & - & - & +1.0 \\
\hline
\end{tabular}

1/ Deviation expressed as plus or minus the first method shown in each comparison made.

2/ Pittsburgh analysis:

3/ A.S.T.M. method run on minus-60-mesh cool.

4) IJlol molsture determination made on alr-dried coal later crushed to stated size. 
Initially, a 500-gram sample of coal was air dried in the slacking oven $22 /$ at $34^{\circ}$ to $35^{\circ} \mathrm{C}$. and 30 percent relative humidity. The time for drying was arbitrarily "shortened to reduce the possibility of oxidation, although the average loss per hour in the last 4 hours was 7.4 percent per hour. At thesend of 7 hours, the air-dry loss was 14.8 percent.

Upon air drying, the sample was crushed to approximately minus-20-mesh. Half of this was next crushed to minus -60 -mesh in a porcelain ball mill; 50 grams was retained as a laboratory sample. Three l-gram samples of the minus-60-mesh coal were heated at $105^{\circ} \mathrm{C}$. for 1 hour in a constant-temperature oven through which a current of air, dried by passing through concentrated sulfuric acid, was forced. The results summarized in table 6 were obtained.

TABLE 6. - Effect of air-drying time and coal size using dried air.

\begin{tabular}{|c|c|c|c|c|}
\hline \multicolumn{5}{|c|}{ Minus-60-mesh coal } \\
\hline Sample No. ............... & & 2 & 3 & $\begin{array}{l}\text { Moisture, } \\
\text { average \% }\end{array}$ \\
\hline $\begin{array}{l}\text { Loss after } 1 \text { hour, gm. } \ldots \ldots \ldots \ldots \ldots \ldots \ldots \ldots \\
\text { Loss after } 2 \text { hours, gm. } \ldots \ldots \ldots \ldots \ldots \ldots \ldots \ldots\end{array}$ & $\begin{array}{r}0.1411 \\
.1423\end{array}$ & $\begin{array}{r}0.1412 \\
.1422\end{array}$ & 0.1431 & $\begin{array}{l}26.9 \\
26.9\end{array}$ \\
\hline
\end{tabular}

Minus-20-mesh coal

\begin{tabular}{|c|c|c|c|}
\hline $\begin{array}{l}\text { Sample No } \\
\text { Loss after } i \text { hour, gm. }{ }^{\prime} \ldots \ldots \ldots \ldots \ldots \ldots \ldots \ldots\end{array}$ & $\frac{1}{0.1400}$ & $\begin{array}{l}2 \\
0.1400\end{array}$ & $\begin{array}{l}\text { Moisture, } \\
\text { average } \% \\
26.7\end{array}$ \\
\hline
\end{tabular}

Average moisture by Bureau of Mines methad.................. $26.8 \%$

From the above table, it is seen that l-gram samples of the minus-60-mesh coal, after drying for 1 hour at $105^{\circ} \mathrm{C}$., showed a maximum variation of 0.0020 gram or 0.2 percent. Two of such samples showed an everage decrease in weight of 0.0011 gram or 0.11 percent after they were replaced in the oven and dried for an additional hour. Two-1-gram samples of the same material ground to minus-20-mesh displayed no variation in weight loss but gave 0.2 percent less moisture than the average of the minus-60mesh samples.

\section{DRYING AT $104^{\circ}-110^{\circ} \mathrm{C}$. WITH NATURAL CIRCULATION OF} AIR FROM THE ROOM

One 100 -gram sample of $1 / 2$ by $1 / 4-1$ rich coal was dried at $104^{\circ}-110^{\circ} \mathrm{C}$. for ? hours. The air-drying loss was 16.2 percent after 2 hours of drying. This partly dried coal was ground to minus 60 -mesh. Total exposure to air due to grinding and handling before sealing in the sample jar was about 10 minutes.

Four 1-gram samples of this minus-60-mesh partly.dried coal were heated for 1 additional hour under the conditions described above. At the end of this period, the samples showed a maximum variation of 0.0050 gram or 0.5 percent. These four samples were heated an additional 30 minutes. Tho samples increased in weight an average of 0.002 gram or 0.2 percent. The other two samples decreased in welght by 0.0023 gram and $0.0044 \mathrm{gram}$, respectively. The moisture value obtained by this method was 26.4 percent under conditions existing in the Denver laboratory. The results of this experiment are given in table 7. "

22] Yancey, H. F., Johnison, K. A., and Sielvig, W. A., Friability, Slacking Characteristics, Low-Temperature Carbonization Assay, and Agglutinating Value of Washingtion and Other Coals: Bureau of Mines Tech. Paper 512, 1932, 94 pp. 
TABLE 7. - Effect of air-drying time, using normal laboratory air

\begin{tabular}{|c|c|c|c|c|c|}
\hline & \multicolumn{5}{|c|}{ Minus-60-mesh coal } \\
\hline Sample No. $\ldots \ldots \ldots \ldots \ldots \ldots$ & 1 & 2 & 3 & 4 & Ave. moisture, percent \\
\hline $\begin{array}{l}\text { Loss } 1 \text { hour } \ldots \ldots \ldots \ldots \ldots \text {. . . . } \\
\text { Loss } 1-1 / 2 \text { hours } \ldots \ldots \ldots . \text {. }\end{array}$ & $\begin{array}{r}0.1226 \\
.1212\end{array}$ & $\begin{array}{r}0.1234 \\
.1213\end{array}$ & $\begin{array}{r}0.1218 \\
.1241\end{array}$ & $\begin{array}{r}0.1184 \\
.1228\end{array}$ & $\begin{array}{l}26.4 \\
24.4\end{array}$ \\
\hline
\end{tabular}

EFT ICACY OF DISTILLATION METHODS FOR.MOISTURE EVALUATION

Table 8 shows the great deviation in results obtained by xylol distillation when coal $1 / 2-$ by $1 / 4-i n c h$ is used. This particular phase of work shows the inherent weakness of a distillation method using large coal particle sizes. The time necessary for the water to travel from within the coal particle to the surface is lengthened.

TABLE 8. - Xylol distillation on $1 / 2-$ by $1 / 4$-inch coal

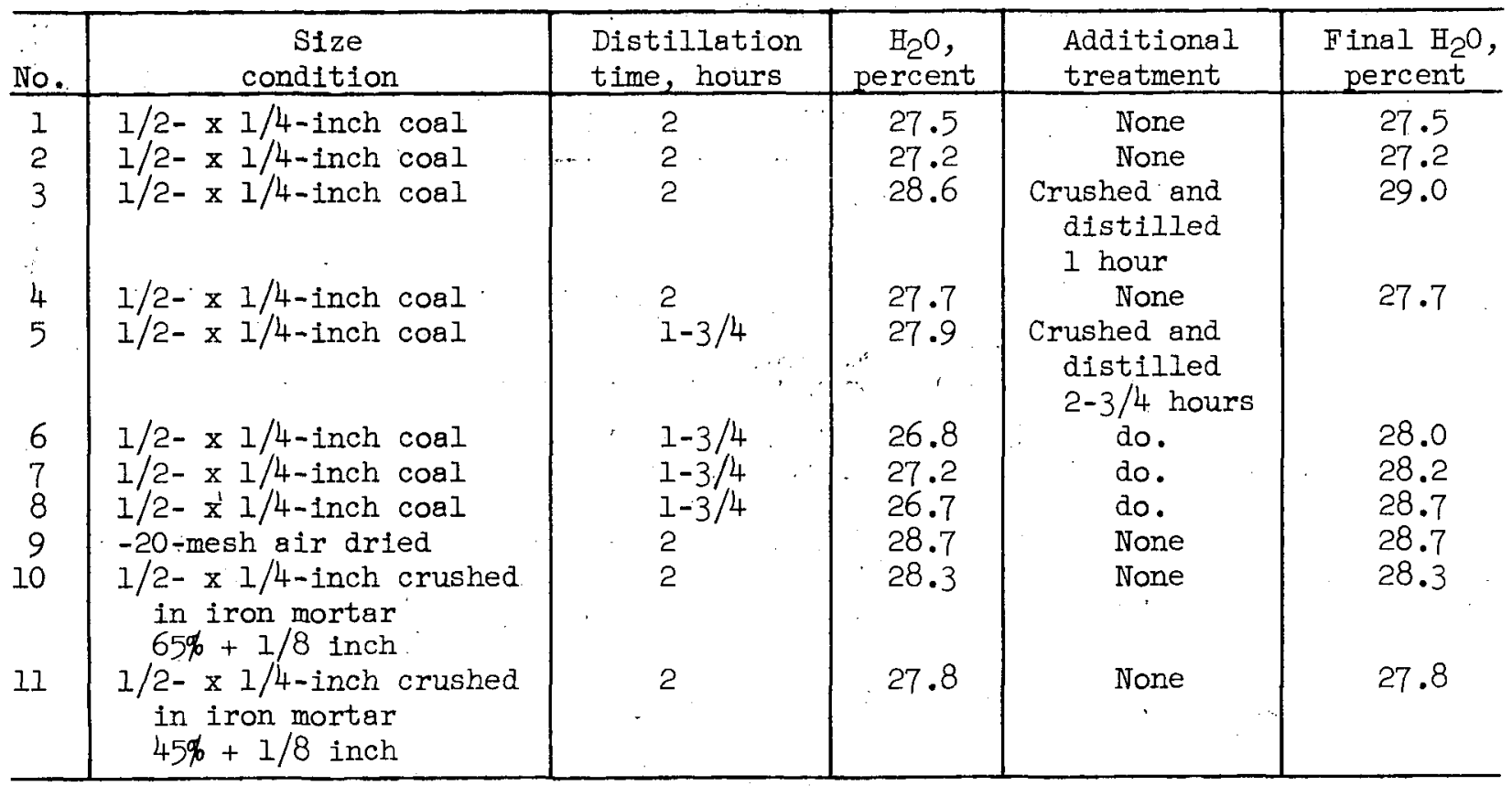

Eight samples of approximately' 50 grams each of $1 / 2$ - by $1 / 4$-inch coal were distilled with xylol for about 2 hours to determine the moisture content of the coal. The average moisture obtained from these 8 samples (Nos. 1 to 8 , inclusive) was 27.5 percent. The maximum difference between any 2 samples recorded was 7 percent, and the maximum deviation from the average was about 4 percent. This same coal crushed before xylol distillation showed an average moisture value of 28.3 percent with 3 samples (Nos. 9, 10, and 11).

Five of these samples (numbers $3,5,6,7$, and 8) were crushed in the xylol after the original distiliation and were then distilled for an additional 1 to 3 hours. The gain in $\mathrm{H}_{2} \mathrm{O}$ ranged from 1.4 to 7.4 percent, the average gain being 3.7 percent. An average of the 5 samples, after redistilling netted $28.5^{\circ}$ percent.

Only 1 Schoch oil-dehydration determination on the $1 / 2-$ by $1 / 4-$ inch coal was done. A sample of about 250 grams gave 28.2 percent moisture. A series of 12 molsture determinations on Dakota Star lignite by both the Schoch oil-dehydration and the xylol distillation methods were made to test the reproducibility of these direct methods on 
coal 1/4-inch by size. These data are summarized in tables 9 and 10 . The variation in either method is less than 1 percent with a coal of this moisture content. The two volumetric methods agree closely. "It is seen that as a direct method either the Schoch oll-dehydration technique or the xylol distillation method can be 'used'with equal effectiveness. However, the simplicity of the method and the ease of handing recommend the xylol method as the superior procedure for routine and control work.

TABLE 9. - Effect of temperature on percentage of water measured; as determined by xylol distillation method

\begin{tabular}{|c|c|c|c|c|}
\hline Dakota S & - lignite & 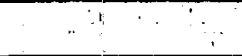 & Coal size: & $1 / 4-$ inch $x \cdot 0$ \\
\hline $\begin{array}{l}\text { Wt. of sample, } \\
\text { grams }\end{array}$ & $\begin{array}{c}\text { Volume } \mathrm{H}_{2} \mathrm{O} \\
\text { distilled, } \mathrm{ml} .\end{array}$ & $\begin{array}{l}\text { Temp. of } \\
\text { water, }{ }^{\circ} \mathrm{C} \text {. }\end{array}$ & $\begin{array}{l}\text { Uncorrected } \\
\text { percent } \mathrm{H}_{2} \mathrm{O}\end{array}$ & $\begin{array}{l}\text { CorrectedIf } \\
\text { percent } \mathrm{H}_{2} \mathrm{O}\end{array}$ \\
\hline $\begin{array}{l}50.1 \\
49.9 \\
49.9 \\
49.4 \\
50.3 \\
51.3 \\
48.6 \\
50.4 \\
52.3 \\
52.9 \\
52.6\end{array}$ & $\begin{array}{l}19.8 \\
19.6 \\
19.6 \\
19.4 \\
19.9 \\
20.2 \\
19.2 \\
19.9 \\
20.6 \\
21.1 \\
20.7\end{array}$ & 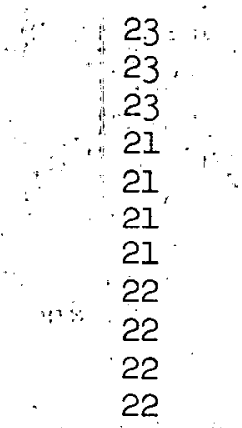 & $\begin{array}{r}39.5 \\
39.3 \\
39.3 \\
39.3 \\
39.6 \\
39.4 \\
39.5 \\
39.5 \\
39.4 \\
39.9 \\
39.4\end{array}$ & $\begin{array}{l}39.4 \\
39.2 \\
39.2 \\
39.2 \\
39.5 \\
39.3 \\
39.4 \\
39.4 \\
39.3 \\
39.8 \\
39.3\end{array}$ \\
\hline
\end{tabular}

I/. Weight of :water corrected for the density at the observed temperature.

TABLE $10 \%$ Effect of temperature on percentage of water measured, $\ldots$ as determined by Schoch oil-distillation method

\begin{tabular}{|c|c|c|c|c|}
\hline \multicolumn{3}{|c|}{ Coal: Dakota Star lignite } & \multirow{2}{*}{$\begin{array}{l}\text { Coal size: } \\
\text { Uncorrected } \\
\text { percent } \mathrm{H}_{2} \mathrm{O}\end{array}$} & \multirow{2}{*}{$\begin{array}{l}1 / 4-\text { inch } \times 0 \\
\text { Corrected } \mathrm{I} \\
\text { percent } \mathrm{H}_{2} \mathrm{O}\end{array}$} \\
\hline $\begin{array}{c}\text { Wt of sample } \\
\text { grams }\end{array}$ & $\begin{array}{l}\text { Volume } \mathrm{H} \mathrm{O} \\
\text { distilled, ml. }\end{array}$ & $\begin{array}{l}\text { Temp of } \\
\text { titration }{ }^{\circ} \mathrm{C} \text {. }\end{array}$ & & \\
\hline $\begin{array}{r}250.3 \\
249.8 \\
250.1 \\
249.9 \\
249.6 \\
250.6 \\
250.5 \\
250.1 \\
249.5 \\
249.1 \\
250.2 \\
250.1 \\
2 \\
250 \\
2\end{array}$ & $\begin{array}{l}98.79 \\
97.70 \\
98.38 \\
98.75 \\
99.00 \\
99.05 \\
99.27 \\
98.85 \\
98.10 \\
98.40 \\
98.79 \\
98.50\end{array}$ & $\begin{array}{r}21 \\
\\
21 \\
22 \\
22 \\
22 \\
22 \\
22 \\
22 \\
22 \\
22 \\
23 \\
23 \\
23 \\
25 \\
25 \\
25\end{array}$ & $\begin{array}{l}39.4 \\
39.1 \\
\because \quad 39.3 \\
39.5 \\
39.7 \\
39.5 \\
39.6 \\
39.5 \\
39.3 \\
39.5 \\
39.5 \\
39.4\end{array}$ & $\begin{array}{c}39.4 \\
39.0 \\
39.2 \\
39.4 \\
39.6 \\
39.4 \\
39.5 \\
39.4 \\
39.2 \\
39.4 \\
39.4 \\
39.3\end{array}$ \\
\hline
\end{tabular}

If Weight of water'corrected for the density at the observed temperature.

An excellent demonstration of the practicality of the xylol distillation method was shown by Brender-a-Brand is and Vergeer. 3 \% They instituted a comparative study of the accuracy of different methods of determining the true moisture content of a lignite. Their methods and results are briefly sumarized as follows:

23 Brender-a-Brandis, G. A., and Vergeer, C. J., (Determination of the True Moisture Content of Lignite): Brennstoff Chem., vol. 3, 1922, pp. 353-355. 
1. Dried in a desiccator over $\mathrm{CaCl}_{2} \ldots \ldots \ldots \ldots \ldots \ldots \ldots \ldots$

$\frac{\text { Moisture, percent }}{49.75}$

Distillation methods (azeotropic distillation)

8. Distillation with petroleum solvent to $155^{\circ} \mathrm{C}, \ldots$. 54.12

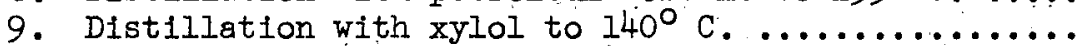
53.72

Methods in wh1ch evolved moisture is absorbed by $\mathrm{CaCl}$ ? and subsequently estimated gravimetrically

10. In a current of nitrogen at $100^{\circ}-105^{\circ} \mathrm{C} . . . . . . .$.

11. In a current of oxygen at $100^{\circ}-105^{\circ} \mathrm{C} . \ldots \ldots \ldots \ldots$.

From a critical study of the methods and results, the investigators opined that drying in a current of nitrogen and subsequent absorption and gravimetric estimation of the evolved water were the most accurate and compared very favorably with xylol distillation as an alternate method.

In precise analytical work temperature corrections may be introduced. This may be accomplished by taking the temperature of the water distilled into the receiver at the end of the distillation period. Correction can then be made for the weight of the water at that temperature, and that weight can then be converted to a percent of the original coal. As shown in tables 9 and 10, this correction amounts to about 0.1 gram ( 0.25 percent) over a temperature range $21^{\circ}$ to $25^{\circ} \mathrm{C}$., with a coal having a moisture content of about 39 percent.

A second correction involves the amount of water that remains dissolved in the xylene at the end of the distillation. At $25^{\circ} \mathrm{C}$., this correction is less than 0.01 gram, which is well beyond the limit of accuracy of the method. "For routine and control work, this refinement may be ignored.

The problem of the probable error owing to the solubility of water in xylene has been closely studied by Simek and 'Ludmila.24 They used water-free xylol and watersaturated xylol in their comparative moisture estimation studies. Water-saturated xylol was used in the earlier distillation apparatus where no reflux return system was used; however, with the current Stark-Dean distillation trap or the apparatus shown by Simek and Iudmila, water-saturated xylol has no practical use.

It is shown that the solubility of xylene is water is beyond the limit of practical error for the xylol distillation method; for example, at $10^{\circ} \mathrm{C}$. xylene contains 0.0185 percent of water, and at $25^{\circ} \mathrm{C}$. It contains 0.0384 percent of water. Similar solubility values are shown by Uspenski, $25 \%$ and in Landolt-Bölernsteln. $26 /$ Their work showed a possible recovery of 99.41 percent, of the theoretical water in the lignite and coal samples.

24/ Simek, B. G., and Ludmila, J., The Determination of Moisture in Solid Fuels: Fuel, vol. 26, No. 5, 1947, pp: 132-137.

25/ Uspenski, S. P., Chem. Zentralb., vol. 1930, II, 1942.

26) Landolt-B̈̈ernstein, Physikalisch-chemische Tabellen: Julius Springer, Berlin, 3d Suppl., 1935, p. 672. 
In a hypothetical case, where $25 \mathrm{ml}$. of water is recovered as moisture, accompanied by a supernatant layer of $5 \mathrm{ml}$. of xylol (as in an ordinary Stark-Dean apparatus), it can be shown that the error due to water solubility in the xylene is insignificant and even less than that shown by the aforementioned workers.

In corroborating the current work, it is appropiriate that the work of Simek and Ludmila27./ be discussed. This comprehensive study b.y these investigators is the most recent on the subject. Their study, in effect, was to find one of the azeotropic distillation methods that would compare with the highly precise method of drying the coal in a current of dried nitrogen at $130^{\circ} \mathrm{C}$. With subsequent absorption of the evolved water vapor by calcium chloride and gravimetric estimation. A wide variety of coal ranks were studied, eight in all, by a number of different methods. These are best presented by. table 11 abstracted from their. paper:

TABIE 11. - Results of determination of moisture at different temperatures I/

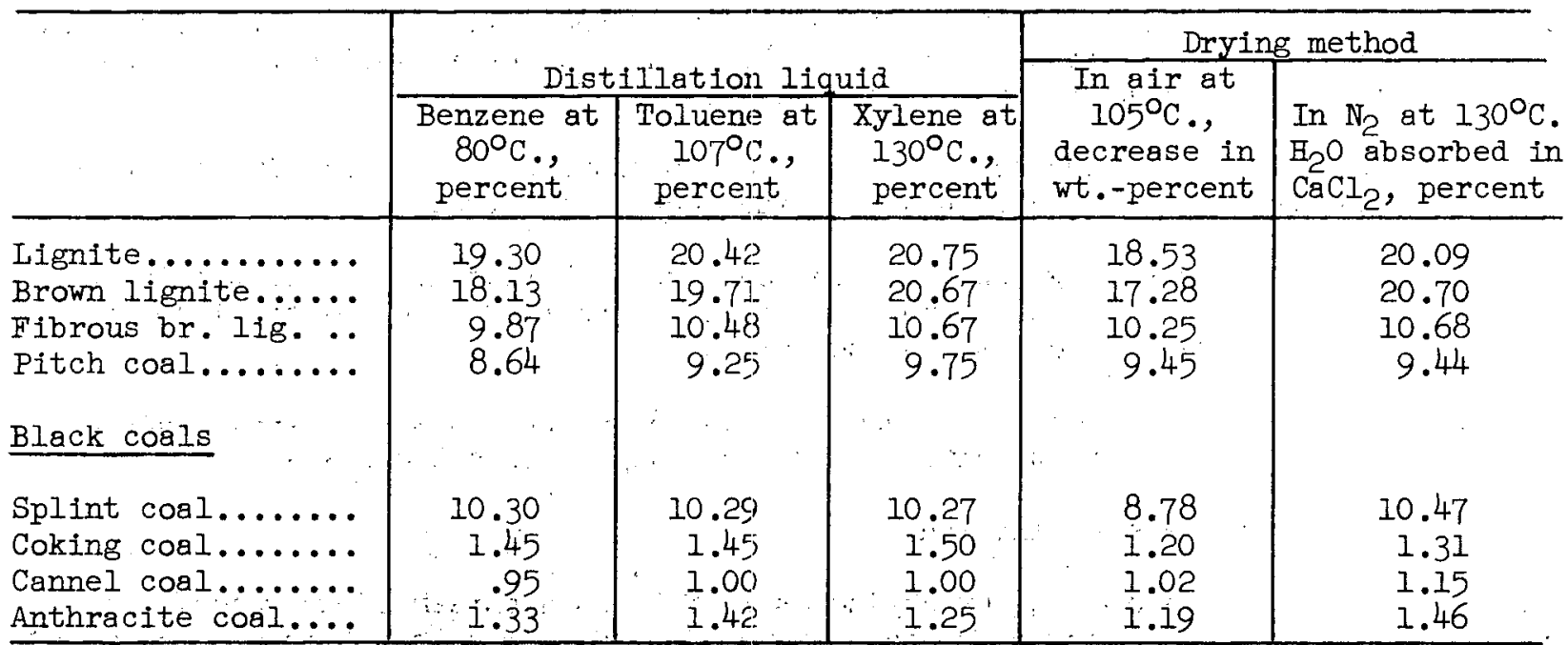

I/ Simek, B. G. and Ludmila, Jaroslav, Fuel, vol. 26, No: 5, 1947, pp. 132-137.

Their table shows that temperature has influence only on results of water determination in brown lignites (lower ranks), whereas tests with their "black cools". show virtually the same results. This difference in contrast to the good agreement obtained with the black coals is explained as being caused by the colloidal structure of the humus fraction of the coal.. In comparing the xylol distillation procedure with conventional drying at $105^{\circ} \mathrm{C}$., it is shown that all the water contained' in a sample of colol is not ineasured by the oven technique: It. was found that good agreement as to the quantity of water measured exists between.the xylol method and the more elaborate or direct method of moisture determination by drying in a stream of heated nitrogen gas with subsequent gravimetric absorption." For this reason, these investigators believe the use of the xylol method to be fully justified.

The temperature:: of : $130^{\circ}$ to $140^{\circ} \mathrm{C}$. for drying via azeotropic distillation has been found to be most suitable because of theoretical and practical considerations. The problem centers about the question concerning the condition of water in coal.

27/ See footnote 18 . 
If the predominant forces holding the water in coal are chemical in nature, as has been suggested,28/ and less a matter of adsorptive capacity through the porous capillary structure of coal, a reasonable doubt is inferred as to the validity of heat-treating oven methods that employ an empirically stated temperature or of the azeotropic distillation of coal in a water immiscible liquid. The experience in this laboratory has been that treatment of low-rank coal by the. Schoch oil-dehydration method causes incipient coal decomposition, if carried to an end temperature beyond $250^{\circ} \mathrm{C}$., with only a slight increase in the total water measured. If the distillation is carried to about $340^{\circ} \mathrm{C}$., a progressively greater amount of water is measured. Under conditions of carbonization, where retorting temperatures just beyond those of initial coal decomposition (about $300^{\circ} \mathrm{C}$.) are maintained, the water of decomposition is about 1:8 percent for low-rank coals.29\% It is particularly significant, however, that water measured by the Schoch method operating at a temperature just below that of incipient coal decomposition is no greater than that measured by the xylol method operating at a temperature of $130^{\circ}$ to $140^{\circ} \mathrm{C}$. Determinations made using toluene, with a boliling point of about $110^{\circ} \mathrm{C}$. , as the distilling liquid (see table 1l) yield slightly less water than can be accounted for by the xylol method. This fact implies two conditions:

(1) $110^{\circ} \mathrm{C}$. may be too low a distilling temperature for determining the water in a low-rank coal unless a compensatory time factor is introduced.

(2) The forces holding the water in coal are such that $110^{\circ} \mathrm{C}$. is too low a temperature to liberate all the water in the coal (short of decomposition) however long the time of distillation at that temperature.

After comparing all deductions and results, Simek and Ludmila have suggested the following methods as most suitable for the analysis of solid fuels:

(1) Direct xylol distiliation.

(2) Direct determination by drying at $130^{\circ} \mathrm{C}$. in a stream of nitrogen. Both methods have been in use for many years at the Coal Research Institute at Prague and have proved accurate and efficient.

28/ Bond, R. L., Griffith, M., and Maggs, F. A. P., Water in Coal: Fuel, Jour. Fuel Sci., vol. 29, No. 4, 1950, pp. 83-93.

Malherbe, P. Le R., Microstructure of Some South African Coals: Fuel, Jour. Fuel Sci., vol. 30, No. 5, 1951, pp: 97-109.

Mukherjee, P. N., Basak, N. G.; and Lahiri; A., Chemisorption of Moisture on Coal: Fuel, Jour. Fuel. Sci., vol. 30, No. 9, 1951, pp. 215-216.

Lecky, J. A., Hall, W. K., and Anderson, R. B., Adsorption of Water and Methanol on Coal: Nature, vol. 168, No. 4264, July 12, 1951, p. 124.

Dionis, Tadeo Oros, (Application of X-ray Methods to the Study of Coal): Combustibles, vol.11, No. 55, 1951, pp. 56-70.

Kreulen, D. J. W., (The Adsorption Water of Coal): Chem. en Pharm. Tech. (Dodrecht), vol. 7, 1951, pp. 23-24.

29/ Parry, V.F., Goodman, J. B., and Gomez, Manuel, Low-Temperature Distillation Assays of Representative Western United States and Alaska Coals: Colorado Sch. Mines Quart., vol. 45, No. 2-A, April 1950, pp. 133-162.

Int. - Bu. of Mines, Pgh., Pa. 